Article

\title{
Reuse of Heat Resistant Glass Cullet in Cement Composites Subjected to Thermal Load
}

\author{
Aleksandra Powęzka ${ }^{1, *(\mathbb{D}}$, Jacek Szulej ${ }^{2}\left(\mathbb{D}\right.$ ) and Paweł Ogrodnik ${ }^{3}$ (i) \\ 1 Faculty of Security Engineering and Civil Protection, Main School of Fire Service, 01-629 Warsaw, Poland \\ 2 Faculty of Civil Engineering and Architecture, Lublin University of Technology, 20-618 Lublin, Poland; \\ j.szulej@pollub.pl \\ 3 Institute of Security Engineering, Main School of Fire Service, 01-629 Warsaw, Poland; \\ pogrodnik@sgsp.edu.pl \\ * Correspondence: apowezka@sgsp.edu.pl
}

Received: 31 July 2020; Accepted: 2 October 2020; Published: 5 October 2020

\begin{abstract}
The article describes the possibility of using waste glass cullet as an alternative aggregate for the production of cement composites. Three concrete mixes based on Portland cement CEM I $42.5 \mathrm{R}$ with different contents of recyclate were designed. Borosilicate glass cullet was introduced into the batch by reducing the content of natural aggregate by $0 \%, 2.5 \%$ and $7.5 \%$. Apparent density, water absorption and compressive strength at elevated temperature were measured. The temperature distribution, in cubic samples, was followed by thermocouples. The elements were heated in a special furnace at the temperatures of $200{ }^{\circ} \mathrm{C}, 400{ }^{\circ} \mathrm{C}, 600{ }^{\circ} \mathrm{C}$ and $800{ }^{\circ} \mathrm{C}$. The composite topography and phase composition were observed using X-ray energy scattering electron microscopy. The results show that the appropriate modification of the cement composite with $2.5 \%$ heat-resistant glass cullet improves both the thermal and mechanical properties. Compressive strength reaches an average value of $48.6 \mathrm{MPa}$ after 28 days. The increase in temperature weakens the structure of the composite. It was found that the obtained cement composite has good physico-chemical properties. The research results are presented in the article.
\end{abstract}

Keywords: recycled aggregates; cullet; cement composite

\section{Introduction}

Glass is commonly used in the construction industry and in various industries branches. It is an inspiration in the search for new applications that require an interdisciplinary approach to the design and implementation processes [1].

Glass is distinguished by its transparency and is also a relatively hard material. Depending on its brand, it occupies the fifth or sixth position in the 10-level Mosh hardness scale. Its main weakness is its fragility. It is made of glass sand (source of silica $\mathrm{SiO}_{2}$ ), borax (source of glass forming component $\mathrm{B}_{2} \mathrm{O}_{3}$ ), sodium-potassium feldspar (source of $\mathrm{Al}_{2} \mathrm{O}_{3}$ ), sodium carbonate, limestone and others. Components of glass brands used in the construction sector comprise circa $70-72 \% \mathrm{SiO}_{2}$, circa $15 \% \mathrm{Na}_{2} \mathrm{O}$, circa $10 \%$ $\mathrm{CaO}$, as well as $\mathrm{MgO}, \mathrm{Al}_{2} \mathrm{O}_{3}$ and other ingredients adopted to improve the properties of glass or to streamline the production process [2]. Glass is a fragile material, which means that once it reaches its maximum strength, it cracks and becomes crushed. Compared to steel or concrete, glass is characterised by high compressive strength equalling to $0.8-1 \mathrm{GPa}$. The tensile and flexural strength of glass is much lower and equals 30-90 MPa. In addition, glass has a high Young's modulus equalling to circa $70 \mathrm{GPa}$. This value is comparable to the Young's modulus of aluminium [1]. Apart from traditional functions, glass is meant among others to insulate and to protect from burglary or from a fire. The resistance of ordinary glass to high temperatures, such as those that occur during a fire, is very low. After a few 
minutes it becomes completely destroyed. Construction glass (single-layer silica glazing) cracks and falls out of the frame after being heated to $200{ }^{\circ} \mathrm{C}$. Much better properties are offered by reinforced silicate glass, which may crack, yet it does not fall out from the frame that holds it. Borosilicate glass is characterised by a high chemical resistance, withstands high temperatures for a longer time, maintains tightness, but concurrently also permits passage of thermal radiation to the protected zone. It is also characterised by "flexibility" at fire temperature that prevents its cracking [3].

Studies carried out to date indicate that glass waste constitutes 7-10\% of all waste deposited on landfills. Recycling of cullet limits the usage of sand, limestone, soda, etc., as well as even water, by $50 \%$ with concurrent reduction of energy by circa $30 \%$. This allows lowering the emission of contamination to the atmosphere. Approximately $30 \%$ of glass packaging items are processed to cullet. Each obtained tonne of glass cullet allows a saving $800 \mathrm{~kg}$ of sand, $250 \mathrm{~kg}$ of soda and $180 \mathrm{~kg}$ of limestone powder. This shows that the usage of glass from recycling contributes to a reduction in the volume of landfills and widely promotes the circular economy $[4,5]$.

In response to social needs, the necessity of maintaining the market competitiveness and a user friendly natural environment, research implemented to date with respect to elementary features of composites using concrete and ceramic recyclates and cullet go along with the concept of sustainable construction engineering. Recycling of waste glass seems to be an advantageous solution in production of raw materials and manufacturing of secondary products, for example in the sector of civil engineering (recycling of construction aggregate) [6-10].

Glass used for the production of concrete needs to undergo a special processing procedure $[5,11]$. The whole material may be recycled. It should be borne in mind that glass from broken mirrors, window and car glazing, glasses, wine glasses, heat resistant dishes, light bulbs, ceramic products, porcelain and earthenware articles, bowls, plates, grave candles, medication glass packaging, etc. may not be processed in furnaces designated for cullet obtained from packaging elements [12]. Before it may be added to the concrete mixture, recyclate needs to be tested, because it changes properties of the mixture and hardened cement composite; among other effects it delays hydration and prolongs the initial and final setting time.

Numerous researchers are looking for innovative solutions that would meet performance requirements and determine the inventive nature of the use of waste cullet. Recently conducted studies [13-24] enable the determination of the suitability of using waste materials for the production of ceramics, binders, mortar, concrete, plaster, bituminous materials etc. For testing requirements, use is made of various types of cullet, from car glazing [25], soda-lime glass from containers [26-28], glass from technological lines of the pharmaceutical industry [29-31], cathode ray tubes for TV sets and computer screens [32,33], float glass from window glazing [5], glass from fluorescent lamps [13], glass from heat resistant dishes [34] and mirrors, safety glass, crystal glass, and colourless, green and brown packaging glass [34-39] among others.

Cullet is used as a substitute for cement, sand and coarse aggregate in concrete, and in addition may be used for stabilisation of natural soils or for the construction of roads and subgrades $[5,40]$. The powder fraction of ground glass may also be used in concrete as a pozzolanic material [41].

When designing a cement composite, cullet may be introduced into concrete in the form of fibres, dust or grains. The addition of glass consisting of fibres [42-50] has an advantageous impact on parameters of concrete. Concrete gains a better strength and is resistant to such environmental factors as humidity, solar radiation, thawing and freezing.

Replacing cement in the concrete mixture with crushed glass powder [37-39] allows the attainment of a composite characterised by better workability and improvement of compressive and flexural strength after a prolonged curing time. Recyclate is characterised by pozzolanic reactivity, which is correlated with average compressive strength [10,51].

When using glass cullet as a substitute for sand [34-37,52], the type of applied glass needs to be taken into consideration. The application of a 10-30\% addition of cullet causes a 10-25\% drop compressive strength in resistance compared to the control sample [53]. 
Studies performed until now have proven that it is possible to adopt a solution based on replacement of coarse natural aggregate by waste aggregate. Studies took into consideration glass [54-57] and ceramic waste [58,59]. From the ecological and economic viewpoint this solution appears to be advantageous, proecological and safe for the environment. It does not require a large amount of work as, for example, in the case of fibres or crushing to a powdered form.

A review of published research $[5,11]$ has shown that no analyses have been implemented yet with respect to recycling of used up heat resistant dishes for the production of concrete. While conducting the research, the authors took into account the feasibility of using glass recyclate as an optional supplementing aggregate for the production of cement composites exposed to thermal loads. Analysis was carried out of selected physical, mechanical and structural properties of the composite.

\section{Materials and Methods}

\subsection{Objective and Scope of Testing}

The objective of the study was to assess the reuse of heat-resistant glass cullet obtained from damaged dishes. During pilot studies, apart from mechanical properties, also determined was the impact of fire temperatures on properties of the designed composite. The article presents the results of tests and analyses of the microstructure of the contact zone of the material.

\subsection{Waste Glass Cullet}

Pilot testing comprised the use of cement composite with diverse additions of recyclate C-0, C-2.5, C-7.5 (C-series of composite made of Portland cement, the number indicates the percentage of glass cullet introduced into the batch by reducing the content of natural aggregate by $0 \%, 2.5 \%$, $7.5 \%$ ). A part of the natural aggregate was replaced by borosilicate heatresistant glass cullet. When selecting recycled aggregate it was necessary to take into account first of all advantageous physical parameters and ecological aspects. The material was obtained primarily from broken glass of kitchen and laboratory dishes stocked on premises of the glass works in Wołomin (Termisil S.A. Glassworks, Wołomin, Poland) [5] (Figure 1). Table 1 presents the properties of glass cullet.

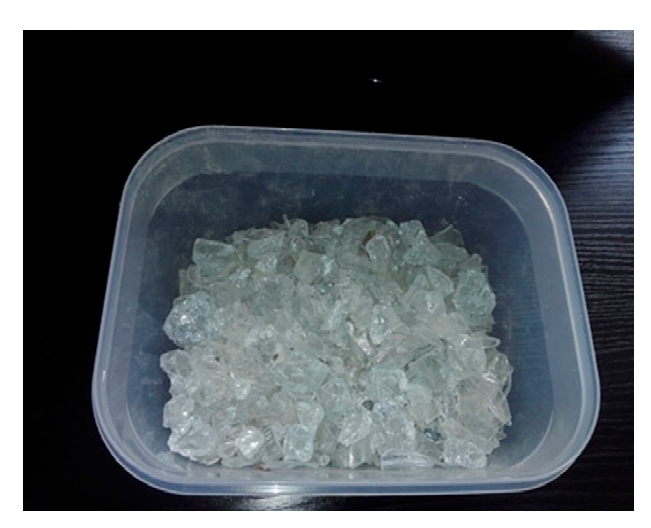

Figure 1. Glass cullet with a fraction of $0 / 16 \mathrm{~mm}$.

Glass ingredients comprise among others silicon oxide $\left(\mathrm{SiO}_{2}\right)$, boron trioxide $\left(\mathrm{B}_{2} \mathrm{O}_{3}\right)$ or aluminium oxide $\left(\mathrm{Al}_{2} \mathrm{O}_{3}\right)$. The isotropic material is characterised by higher resistance to thermal shock with a low thermal expansion coefficient. It retains a good thermal resistance in the working temperature range of $-40{ }^{\circ} \mathrm{C}$ to $500{ }^{\circ} \mathrm{C}$ and withstands temperature difference in the range of $150-210{ }^{\circ} \mathrm{C}$. A granulometric analysis of heat resistant glass cullet is presented in Table 2. The content of dust (total from rinsing and sieving) amounts to $16.1 \mathrm{~g}$, while the density of cullet equals $2.25 \mathrm{~g} / \mathrm{cm}^{3}\left(\right.$ at $\left.20^{\circ} \mathrm{C}\right)$. 
Table 1. Physical and chemical properties of TERMISIL borosilicate glass.

\begin{tabular}{cc}
\hline Component & Requirements \\
\hline Temperature of transformation, ${ }^{\circ} \mathrm{C}$ & 535 \\
Temperature of dilatometric softening, ${ }^{\circ} \mathrm{C}$ & 635 \\
Lower annealing temperature, ${ }^{\circ} \mathrm{C}$ & 520 \\
Upper annealing temperature, ${ }^{\circ} \mathrm{C}$ & 550 \\
Permissible working scope, ${ }^{\circ} \mathrm{C}$ & $-40 \div 300$ \\
Density at $20{ }^{\circ} \mathrm{C}, \mathrm{g} / \mathrm{cm}^{3}$ & 2.23 \\
Hydrolytic resistance of glass grains at temperature of $98{ }^{\circ} \mathrm{C}$ & $\mathrm{HGB} 1$ \\
Average coefficient of linear thermal expansion $\left(30{ }^{\circ} \mathrm{C} ; 300{ }^{\circ} \mathrm{C}\right), \mathrm{K}^{-1}$ & $3.55 \times 10^{-6}$ \\
$\mathrm{SiO}_{2}$, weight $\%$ & 80 \\
$\mathrm{Na}_{2} \mathrm{O}$, weight $\%$ & 4 \\
$\mathrm{~K}_{2} \mathrm{O}$, weight $\%$ & 1 \\
$\mathrm{~B}_{2} \mathrm{O}_{3}$, weight $\%$ & 13 \\
$\mathrm{Al}_{2} \mathrm{O}_{3}$, weight $\%$ & 2 \\
\hline
\end{tabular}

Table 2. Results of sieve analysis. Glass cullet.

\begin{tabular}{ccc}
\hline Mesh Size, $\mathbf{~ m m}$ & Residues on a Sieve, $\mathbf{g}$ & Sifting, $\%$ \\
\hline 63 & 0.00 & 100.00 \\
31.5 & 180.20 & 93.16 \\
16 & 1154.50 & 49.33 \\
8 & 969.00 & 12.54 \\
4 & 243.80 & 3.28 \\
2 & 53.00 & 1.27 \\
1 & 17.30 & 0.61 \\
bottom & 16.10 & 0.00 \\
\hline
\end{tabular}

\subsection{Natural Aggregate}

To prepare cement composites quartz sand was used with a fraction of 0/2 mm (PolBot Kruszywa S.A., Warszawa, Poland) and gravel with a grading of 2/16 mm (Zakład Produkcji Kruszyw Szumno Sp. j., Szumowo, Poland).

\subsection{Cement}

All series of samples were produced based on Portland cement CEM I 42.5 R (Cement Ożarów S.A., Ożarów, Poland) and fly ash. The declared physical, chemical and mechanical properties of cement are presented in Tables 3 and 4.

Table 3. Physical and mechanical properties of cement CEM I 42.5 R [34].

\begin{tabular}{ccccc}
\hline $\begin{array}{c}\text { Start of Binding } \\
\text { Time, } \mathbf{m i n}\end{array}$ & $\begin{array}{c}\text { Volume Stability, } \\
\mathbf{m m}\end{array}$ & $\begin{array}{c}\text { Proper Surface, } \\
\mathbf{c m}^{2} / \mathbf{g}\end{array}$ & $\begin{array}{c}\text { 2-Day Compressive } \\
\text { Strength, MPa }\end{array}$ & $\begin{array}{c}\text { 28-Day Compressive } \\
\text { Strength, MPa }\end{array}$ \\
\hline 180 & 0.6 & 4189 & 31.1 & 55.4 \\
\hline
\end{tabular}

Table 4. Chemical properties of cement CEM I $42.5 \mathrm{R}$ as (\%) [34].

\begin{tabular}{ccccc}
\hline Loss of Ignition & Insoluble Residue & $\mathbf{S O}_{3}$ & $\mathbf{C l}^{-}$ & $\mathbf{N a}_{2} \mathbf{O}_{\mathbf{e q}}$ \\
\hline 2.85 & 0.72 & 3.20 & 0.07 & 0.74 \\
\hline
\end{tabular}

\subsection{Fly Ash}

Mineral additive was used in the mixture that consisted of fly ash ProAsh cat. A (Zakład Separacji Popiołów Siekierki Sp. z o.o., Warszawa, Poland) with pozzolanic properties. The fly ash fulfils criteria imposed by standard EN 450-1:2012 [60]. Concrete that contains fly ash (amounting to 20\%) has better 
strength and resistance to cracking, corrosion and high temperature [10]. The chemical composition of fly ash is presented in Table 5. Fly ash was used, because composites on a cement base with a $20 \%$ additive of ash offer better strength, cracking, corrosion and temperature resistance [5].

Table 5. Physical and chemical properties of fly ash [5].

\begin{tabular}{cc}
\hline Component & Requirements \\
Appearance & grey or dark grey powder \\
Loss of ignition, $\%$ & 4.5 \\
Chlorines $\mathrm{Cl}^{-}, \%$ & 0.1 \\
Anhydride of sulfuric acid $\mathrm{SO}_{3}, \%$ & 0.25 \\
Free calcium oxide $\mathrm{CaO}, \%$ & 0.11 \\
Reactive calcium oxide $\mathrm{CaO}, \%$ & 1.8 \\
Grain density, $\mathrm{kg} / \mathrm{m}^{3}$ & 2050 \\
Volume weakness, $\mathrm{mm}$ & 1 \\
Fineness, $\%$ & 30 \\
Index of pozzolanic activity after 28 days, $\%$ & 80 \\
Index of pozzolanic activity after 90 days, $\%$ & 88 \\
Commencement of binding time as compared to reference concrete of CEM I 42.5R, min & 285 \\
\hline
\end{tabular}

\subsection{Admixtures for Concrete}

Concrete mixtures were produced with the use of a plasticiser admixture that reduces the amount of water-Master Pozzolith 18 BVC (BASF Polska Sp. z o.o., Śrem, Poland). The concrete admixture belongs to a group of surfactants based on lignin sulphonates that are known to enhance the moisturising of cement grains by batched water and to assure better workability of the mixture. Physical and chemical properties of the admixture are presented in Table 6.

Table 6. Physical and chemical properties of the Master Pozzolith 18BVC.

\begin{tabular}{cc}
\hline Component & Requirements \\
\hline Basic raw material & lignin sulphonates \\
Form & liquid \\
Colour & dark brown \\
Density $\left(\right.$ at $\left.20{ }^{\circ} \mathrm{C}\right)$ & $1.10 \pm 0.02 \mathrm{~g} / \mathrm{cm}^{3}$ \\
$\mathrm{pH}\left(\right.$ at $\left.20^{\circ} \mathrm{C}\right)$ & $5.2 \pm 1.0$ \\
Contents of chlorides & $\leq 0.1 \%$ of mass \\
Contents of alkali & $\leq 3.0 \%$ of mass \\
\hline
\end{tabular}

\subsection{Water}

Potable water was used for production of the concrete mixture.

\subsection{Preparation of Concrete Mixture}

Samples for testing were chosen in a random way. The composition of the source mixture is presented in Table 7.

For all the samples a constant water-cement ratio was assumed that equals 0.62. All mixtures were mixed and compacted thanks to the used chemical admixture 18 BVC (BASF Polska Sp. z o.o., Śrem, Poland) that consists of a superplasticiser based on lignin sulphonates.

In addition, the aggregate composition and sand content (SC) of concrete mixtures were determined. The sand content of C-0, C-2.5 and C-7.5 amounted to 47\%, 49\%, 51\%, respectively, in conformity with recommendations presented in EN 933-1: 2012 [61]. The samples were produced as cubes with an edge size of $100 \mathrm{~mm}$, which were then stored in laboratory conditions according to requirements of the standard EN 12390-3: 2009 [62]. A part of the natural aggregate in the mixture was substituted by glass cullet. The following series of mixtures were produced: control mixture C-0 containing entirely sand 
and gravel, C-2.5 containing $2.5 \%$ of glass cullet and C-7.5 containing $7.5 \%$ of glass cullet (percentage change of aggregate to cullet).

Table 7. Weight and volume composition of source mixture.

\begin{tabular}{cccc}
\hline \multirow{2}{*}{ Concrete Ingredients } & \multicolumn{3}{c}{ Concrete } \\
\cline { 2 - 4 } & C-0 & C-2.5 & C-7.5 \\
\hline Cement CEM I 42.5 R, kg/m & 260 & 260 & 260 \\
Fly ash, $\mathrm{kg} / \mathrm{m}^{3}$ & 100 & 100 & 100 \\
Sand 0/2 mm, kg/m & 727 & 727 & 727 \\
Gravel $2 / 16 \mathrm{~mm}, \mathrm{~kg} / \mathrm{m}^{3}$ & 1076 & 1049 & 996 \\
Glass 0/16 mm, kg/m & 0 & 27 & 80 \\
Superplasticiser, $\mathrm{kg} / \mathrm{m}^{3}$ & 1.82 & 1.82 & 1.82 \\
Water, $\mathrm{kg} / \mathrm{m}^{3}$ & 160 & 160 & 160 \\
w/c & 0.62 & 0.62 & 0.62 \\
Sand point, \% & 46.7 & 48.7 & 51.12 \\
Consistence class & $\mathrm{S} 2 / \mathrm{S} 3$ & $\mathrm{~S} 3 / \mathrm{S} 4$ & $\mathrm{~S} 3 / \mathrm{S} 4$ \\
\hline
\end{tabular}

\section{Research Methods}

The technical properties of concrete are a set of all the physical, mechanical, rheological properties and their resistance to the impact of the environment. The article presents a few selected properties of the composite: absorbability, apparent density, compressive strength, deformability under the impact of temperature change (rheological properties), resistance to high temperature and microscopic structure testing.

\subsection{Granulometric Distribution}

Optimum grading is found in the aggregate with the smallest number of cavities between grains, with containing possibly the coarsest aggregate grains. To determine the grading of glass cullet a sieve analysis was carried out. The recyclate was sifted through a set of sieves on a shaker, and then fractions remaining on the sieves and on the bottom were weighed. The test was performed pursuant to standard EN 933-1:2012 [61].

\subsection{Resistance to Grinding Recyclate}

The resistance to grinding was determined by measuring the fragmentation of the aggregate as a result of rolling together the aggregate with steel balls in a rotating drum. The Los Angeles (LA) factor corresponds to the mass of the analytical sample in fragmentation, expressed in $\%$, which has passed through a $1.6 \mathrm{~mm}$ sieve after a complete drum rotation cycle. The test was carried out in accordance with the standard PN-EN 1097-2.

\subsection{Properties of Fresh Concrete}

Tests were conducted of the consistence of concrete mixtures according to the standard EN 12350-2:2009 [63]. The mixture was found to have good workability. The achieved consistence class was S2/S3/S4 according to fall of the Abrams cone; the difference in height of the form and receded mixture was in the range of $75-170 \mathrm{~mm}$. The concrete mixture density was tested according to the standard EN 12350-6:2009 [64].

Before the commencement of proper tests, all the samples were weighed and dried to constant mass in the thermal chamber KC-100/200 (Zalmed, Warszawa, Poland), which was repeated until two consequent measurements were found not to differ one from the other by more than $0.1 \%$, at the temperature of $105^{\circ} \mathrm{C} \pm 5^{\circ} \mathrm{C}$. All measurements of the mass were implemented to within an accuracy of $0.001 \mathrm{~g}$. 


\subsection{Properties of Hardened Concrete}

Test trials were conducted with a view to the determination of physical and mechanical properties. An absorbability test was implemented pursuant to the standard EN 206:2013 [65]. Construction standards define the admissible absorbability of concrete up to $4 \%$. Cement grout coats the grains and hinders the permeation of water, while voids are filled with water and serve as "buffers".

Mechanical tests were carried out in laboratory conditions at room temperature with the use of a hydraulic press. The production and curing of concrete samples designated for compressive strength tests were performed according to the standard PN-EN 12390-2 [66]. The samples were cubic formed, with dimensions of $10 \mathrm{~cm} \times 10 \mathrm{~cm} \times 10 \mathrm{~cm}$, and were placed in a climatic chamber. The elements were unmoulded after $24 \mathrm{~h}$, and marked in a durable and legible way by a symbol defining the type of mixture and number of sample. Immediately after the removal of the elements from the moulds, all of them were once again placed on the grates over the water surface in a climatic chamber to mature for 28 days.

The measurement unit was a Controls Advantest 9 press (Controls, Cernusco sul Naviglio, Italy) including specialist software (Version 2.16-02/2010). Compressive strength is strictly correlated with the microstructure of hardened cement grout and the strength of aggregate and the aggregate-grout contact zone. Compressive strength $\left(f_{c}\right)$ was determined according to the standard PN-EN 12390-3 [62]. On the basis of obtained average strength values, the result was converted onto cubic samples with side length of $15 \mathrm{~cm}$ (according to formula 1) and classes of concrete were defined.

$$
f_{c, \text { cub } 150}=0.95 \times f_{c, \text { cub } 100}
$$

where: $f_{c, \text { cub150 }}$ and $f_{c, \text { cub100 }}$-compressive strength ascertained on cubic samples with edge lengths of 15 and $10 \mathrm{~cm}$, respectively.

\subsection{Tests of Concrete at Elevated Temperature}

The samples were heated at the temperature of $200{ }^{\circ} \mathrm{C}, 400{ }^{\circ} \mathrm{C}, 600{ }^{\circ} \mathrm{C}$ and $800{ }^{\circ} \mathrm{C}$ in a special furnace PK 1100/5 (Termolab S.C., Warszawa, Poland) furnished with powered heating compartments. The stand has a dedicated programme ThermoPro that allows the programming of the thermal process. The temperature distribution in the analysed element was monitored using NiCr-Ni thermocouples that meet criteria defined by the standard [67].

\subsection{Scanning Electron Microscopy with Energy Dispersion Microscopy (SEM/EDS)}

In order to identify phases based on a qualitative chemical analysis and crystalline structure, to obtain high resolution images of the forms of very small items and to obtain spatial differences in the chemical composition, scanning electron microscopy (SEM) was used. The observations were implemented using the FEG Quanta 250 microscope (FEI, Hilsboro, OR, USA) equipped with an EDS system (EDAX, Mahwah, NJ, USA), based on energy dispersion microscopy used to conduct analyses of the chemical composition with the aim of obtaining maps of the distribution of elements and spot chemical analyses of the material. This enabled the determination of semi-quantitative chemical composition of the observed phases. The EDS detector analyses X-ray radiation that indicates the elemental composition of the tested sample.

Using the X-ray diffractometer (PANalytical, Almelo, The Netherlands), analyses were performed of the topography and phase composition of the designed composite. Materials needed for testing were obtained from fragments of crushed samples remaining from the strength testing.

Samples for SEM testing were coated with powder and fixed to the grip with the use of a carbon adhesive. Next the samples were given a circa $50 \mathrm{~nm}$ carbon coating as a result of cathode spraying to assure conductivity on the sample surface. 


\section{Results and Discussion}

The objective of the test was to find how waste cullet affects the properties of cement composite. The research population comprised three modified composites (C-0, C-2.5, C-7.5) containing various amounts of recycled aggregate $(0 \%, 2.5 \%, 7.5 \%)$. From each population 15 samples were collected. The experiment includes observations and assessment of selected properties of the sample (statistical features).

A granulometric analysis was carried out for glass cullet. Tests comprised assessment of the density, absorbability (humidity), compressive strength, resistance to elevated temperature, composite structure, and topography of the tested material. Chemical elements contained in the composites were identified.

\subsection{Granulometric Analysis of Waste Cullet using the Sieve Method}

Granulometric determination was done on a glass sample obtained from recycling, and then a calculation was made of the degree of uniformity. Results of the sieve analysis were applied onto a semi-logarithmic grid and in such a way that a continuous grading curve was obtained (Figure 2) for recycled aggregate.

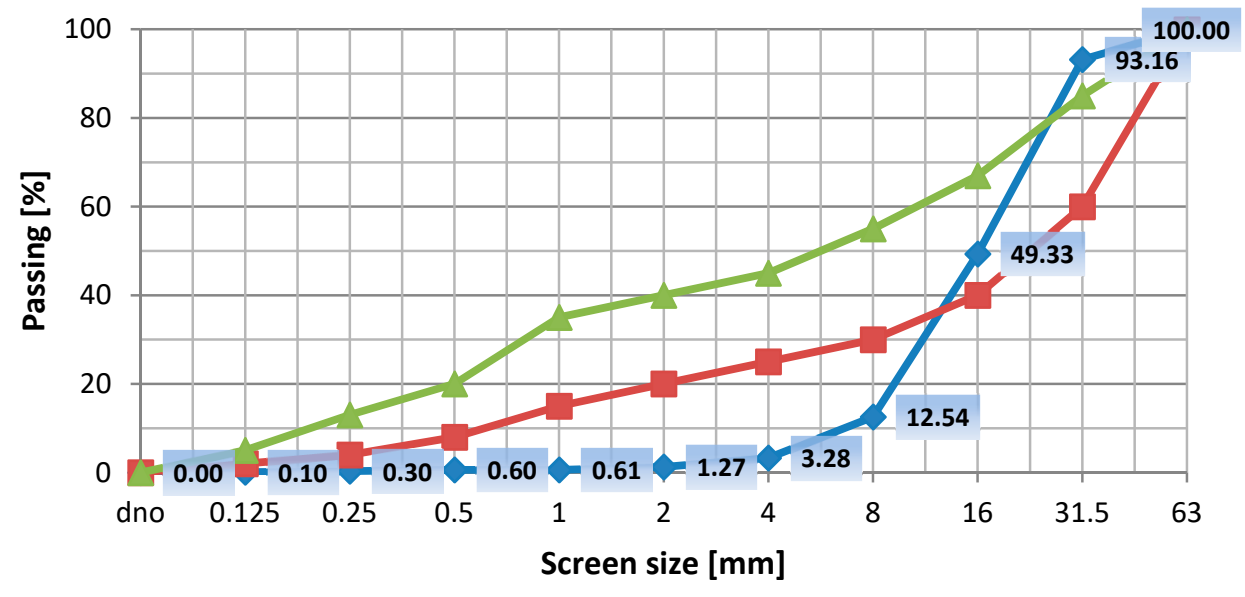

$\neg$ Recycled curve $\_$Lower boundary curve $\rightarrow$ Upper boundary curve

Figure 2. Graphical presentation of the sieve analysis. Grading curves. Recyclate curve compared to the standard good grading field.

The glass aggregate curve is not contained within the area of the limiting sifting curves (upper and lower ones). The sand content of recyclate equals $1.27 \%$. The recyclate fails to meet standard requirements of particularly good grading. The recyclate curve is below the lower limiting curve, yet that does not discriminate recyclate as an additive to concrete. The glass mixture comprises aggregate with a fraction of $0 / 16 \mathrm{~mm}$.

\subsection{Aggregate Resistance to Grinding—Los Angeles Method}

Steel spheres and a $5000 \mathrm{~g}$ analytical sample were placed in the Los Angeles drum (Figure 3). 500 rotations of the drum were performed, with a constant speed of 31-33 rpm. After 16 rotation cycles, the sample was wet sieved on a $1.6 \mathrm{~mm}$ sieve, according to PN-EN 933-1. The residue on a $1.6 \mathrm{~mm}$ sieve was dried at a temperature of $110 \pm 5{ }^{\circ} \mathrm{C}$ to a constant weight- $3134 \mathrm{~g}$. The test result is a Los Angeles (LA) coefficient of 37.32 so the LA fragmentation category is $\mathrm{LA}_{40}$. On this basis, the strength class of the cement composite (C16/20 to $\mathrm{C} 30 / 37)$ was determined for which the glass cullet can be used. 


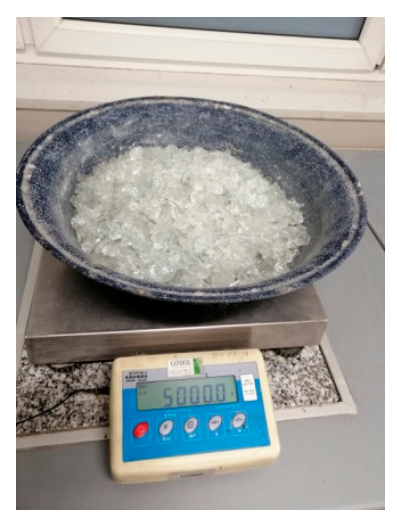

Figure 3. Glass cullet. Analytical sample.

\subsection{Physical Properties of Hardened Concrete}

Bulk density (apparent density) was tested on cubic samples $(100 \times 100 \times 100) \mathrm{mm}$. For the testing three samples of each concrete were used. Results of the test are shown in Table 8 and Figure 4.

Table 8. Apparent density of concrete.

\begin{tabular}{cccc}
\hline Concrete & C-0 & C-2.5 & C-7.5 \\
\hline Measurement 1 & 2378 & 2334 & 2287 \\
Measurement 2 & 2391 & 2363 & 2345 \\
Measurement 3 & 2391 & 2330 & 2350 \\
Average density, $\mathrm{kg} / \mathrm{m}^{3}$ & 2386.7 & 2342.3 & 2327.3 \\
Standard deviation from test, $\mathrm{kg} / \mathrm{m}^{3}$ & 7.51 & 18.01 & 35.02 \\
Standard error, $\mathrm{kg} / \mathrm{m}^{3}$ & 4.33 & 10.40 & 20.22 \\
Variability coefficient, $\%$ & 0.31 & 0.77 & 1.51 \\
\hline
\end{tabular}

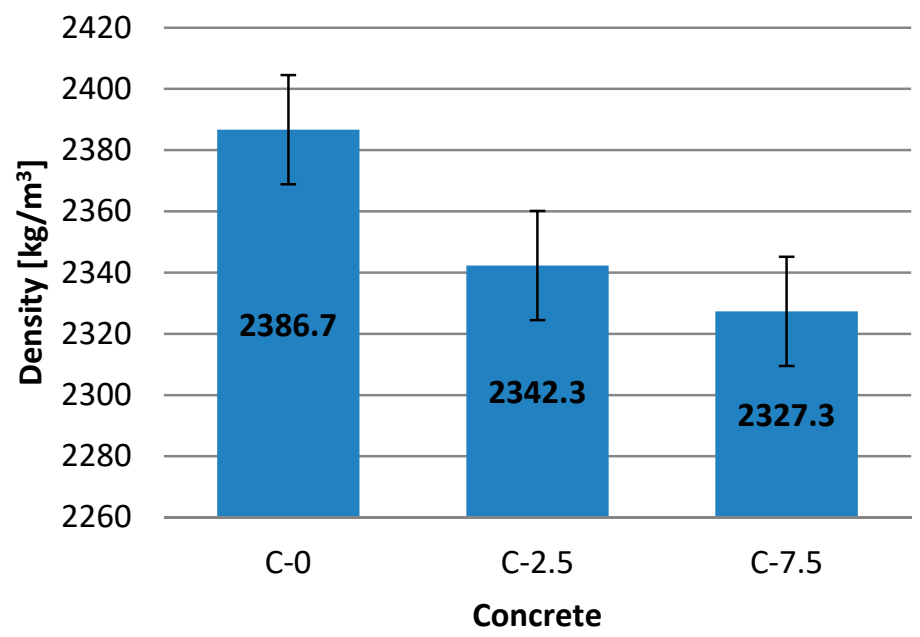

Figure 4. Results of bulk density testing.

Bulk density decreases with the increase in the amount of recyclate in the sample, and differs for all types of concrete. Cement composite C-7.5 with the addition of glass recyclate obtained a density of $2327.3 \mathrm{~kg} / \mathrm{m}^{3}$. The reduced density could have been caused by building up of the contact zone between the binder and aggregate. The porosity of the composite is also affected by reaction of the used aggregate and the binder. Changes in the zone of adhesive-aggregate were also observed in studies $[5,68]$. However, in publication [13] certain differences have been observed in density, caused by the growing contents of air in the mixture. 
The subsequent test comprised the determination of total absorbability (humidity) of the material by the weight method. Tests comprised 15 samples of each type of concrete. Next the samples were dried to constant mass. Constant mass is achieved when sample masses does not differ one from another by $0.1 \%$. After saturation with water the samples were heated up to a temperature of $105 \pm 5{ }^{\circ} \mathrm{C}$ for $72 \mathrm{~h}$, and then they were taken out and weighed. Reinserted for $24 \mathrm{~h}$. After that time, the samples were taken out and measured. A total of seven cycles of this type were carried out.

The saturation time of samples and their drying are determined by standard EN 13369:2018 [69] concerning concrete precast elements. The minimum time amounts to 3 days at change of mass below $0.1 \%$. The authors observed similar drying times of concrete cubes $(10 \mathrm{~cm})$ as observed in the studies of [70]. The drying time of samples to constant mass was 6 to 8 days.

Figure 5 presents results and an image of changes to absolute humidity of concrete during the process of moisture removal. The elementary descriptive statistics are provided in Table 9.

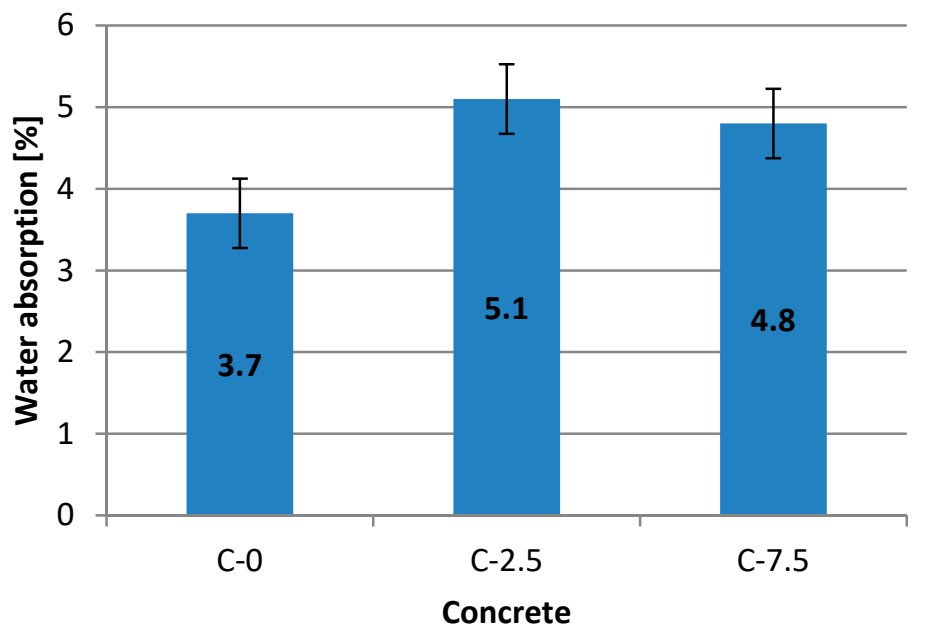

Figure 5. Water absorption of $10 \mathrm{~cm}$ cubes.

Table 9. Elementary statistics for water absorption.

\begin{tabular}{cccc}
\hline Concrete & C-0 & C-2.5 & C-7.5 \\
\hline Average absorbability, \% & 3.7 & 5.1 & 4.8 \\
Standard deviation from test, \% & 0.18 & 0.26 & 0.25 \\
Standard error, $\%$ & 0.05 & 0.07 & 0.06 \\
Variability coefficient, \% & 4.77 & 5.02 & 5.10 \\
\hline
\end{tabular}

Water absorption varied, and for mixtures C-0, C-2.5 and C-7.5 amounted to $3.7 \%, 5.1 \%$ and $4.8 \%$, respectively. The difference in results of absorbability was $1.1-1.4 \%$. This proved that, as the amount of glass aggregate grows, the absorption of concrete also grew, most likely also leading to the formation of air voids in the concrete volume. While analysing the results of their own studies, the authors of [5] also drew attention to the increase in the variability index with contents of glass waste. This is further proof that as the amount of waste grows, the samples become less homogeneous.

The figure also shows error bars with standard error that equals $0.05 \%$ for concrete C- 0 and $0.07 \%$ for C-2.5 and $0.06 \%$ for C-7.5. The water absorption obtained during testing is lower than $6 \%$. According to standards pertaining to precast concrete and sidewalk elements (pavement, concrete kerbs), they should be considered as satisfactory for any class. 


\subsection{Compressive Strength}

The compressive strength test was performed after 28 and 180 curing days of the cement composite. Samples were tested at the laboratory temperature of $20^{\circ} \mathrm{C}$. Three samples were used to determine average strength. The obtained results are presented in the bar chart (Figure 6).

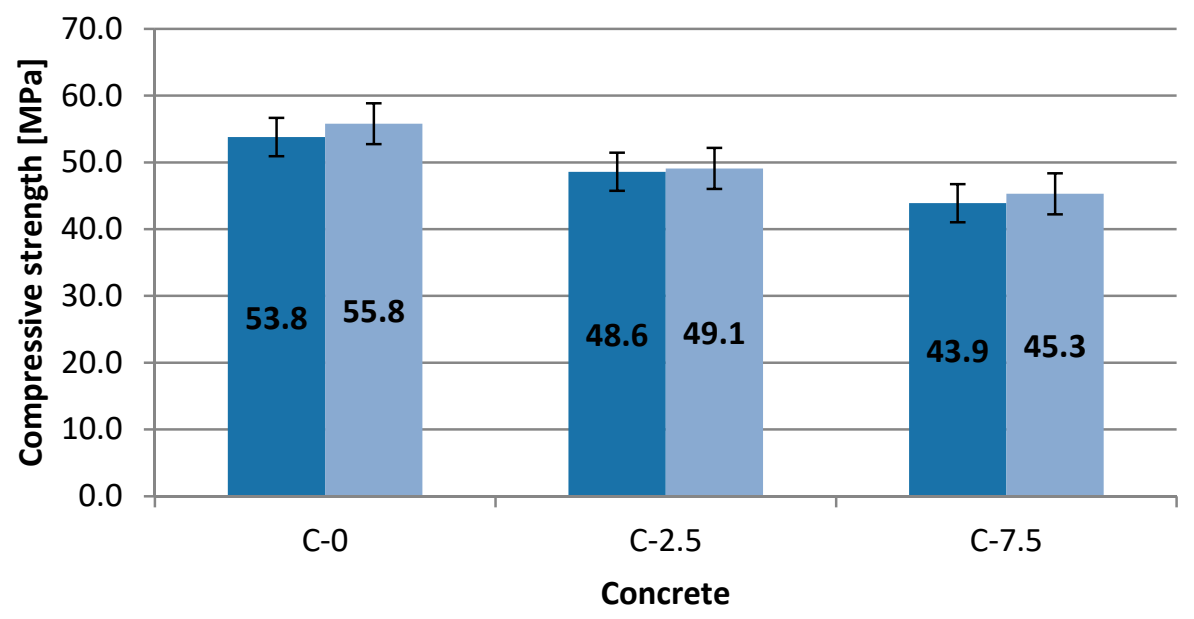

after 28 days after 180 days

Figure 6. Compressive strength of concrete- $10 \mathrm{~cm}$ cubes.

Destructive testing was carried out on samples that had not been subjected to heating. Lower values for concrete C-2.5 and C-7.5 were observed compared to reference concrete C- 0 after 28 days of curing. The differences in values vary and appear to have a downtrend. Compressive strength falls with the amount of waste glass in the sample. It has been found that strength after 180 days for C-7.5 was by 3.8 MPa higher than in sample C-2.5 and concurrently lower by $10.5 \mathrm{MPa}$ than for reference concrete $\mathrm{C}-0$. The target strength on control samples amounted to 55.8 MPa. The conducted testing allows the presumption that a higher strength of the composite was obtained by substituting $2.5 \%$ of gravel with recyclate. Results obtained from all the tested composites may be considered to be satisfactory. The concrete was classified as C30/37, i.e., lower by one class (C35/45) or two classes (C40/50) obtained after 28 and 180 days by reference concrete C- 0 .

Table 10 specifies selected statistical parameters for analysed results of compressive strength. Those parameters characterise the homogenous nature of concrete.

Table 10. Basic statistical parameters. Features of concrete.

\begin{tabular}{|c|c|c|c|}
\hline Concrete & $\mathrm{C}-0$ & C-2.5 & C-7.5 \\
\hline \multicolumn{4}{|c|}{ After 28 days } \\
\hline Average compressive strength, $\mathrm{MPa}$ & 53.8 & 48.6 & 43.9 \\
\hline Standard deviation in test, $\mathrm{MPa}$ & 0.65 & 0.67 & 1.19 \\
\hline Standard error, $\mathrm{MPa}$ & 0.38 & 0.38 & 0.69 \\
\hline Variability coefficient, $\%$ & 1.21 & 1.37 & 2.72 \\
\hline \multicolumn{4}{|c|}{ After 180 days } \\
\hline Average compressive strength, $\mathrm{MPa}$ & 55.8 & 49.1 & 45.3 \\
\hline Standard deviation in test $\mathrm{MPa}$ & 1.90 & 1.05 & 0.25 \\
\hline Standard error, $\mathrm{MPa}$ & 1.10 & 0.61 & 0.15 \\
\hline Variability coefficient, $\%$ & 3.41 & 2.14 & 0.56 \\
\hline
\end{tabular}


The next destructive testing was performed on heated cubes after 180 days of curing. Heating was performed for three cubes each for temperatures of $200^{\circ} \mathrm{C}, 400{ }^{\circ} \mathrm{C}, 600^{\circ} \mathrm{C}$ and $800{ }^{\circ} \mathrm{C}$. The heating process progressed in line with the standard temperature-time curve according to EN 1991-1-2. Temperature in the furnace was kept up for a further $60 \mathrm{~min}$ until the heating process was completed. Testing of average compressive strength took place at room temperature after total cooling down. Figure 7 shows the results of average strength of concrete samples and presents error bars with the standard error.

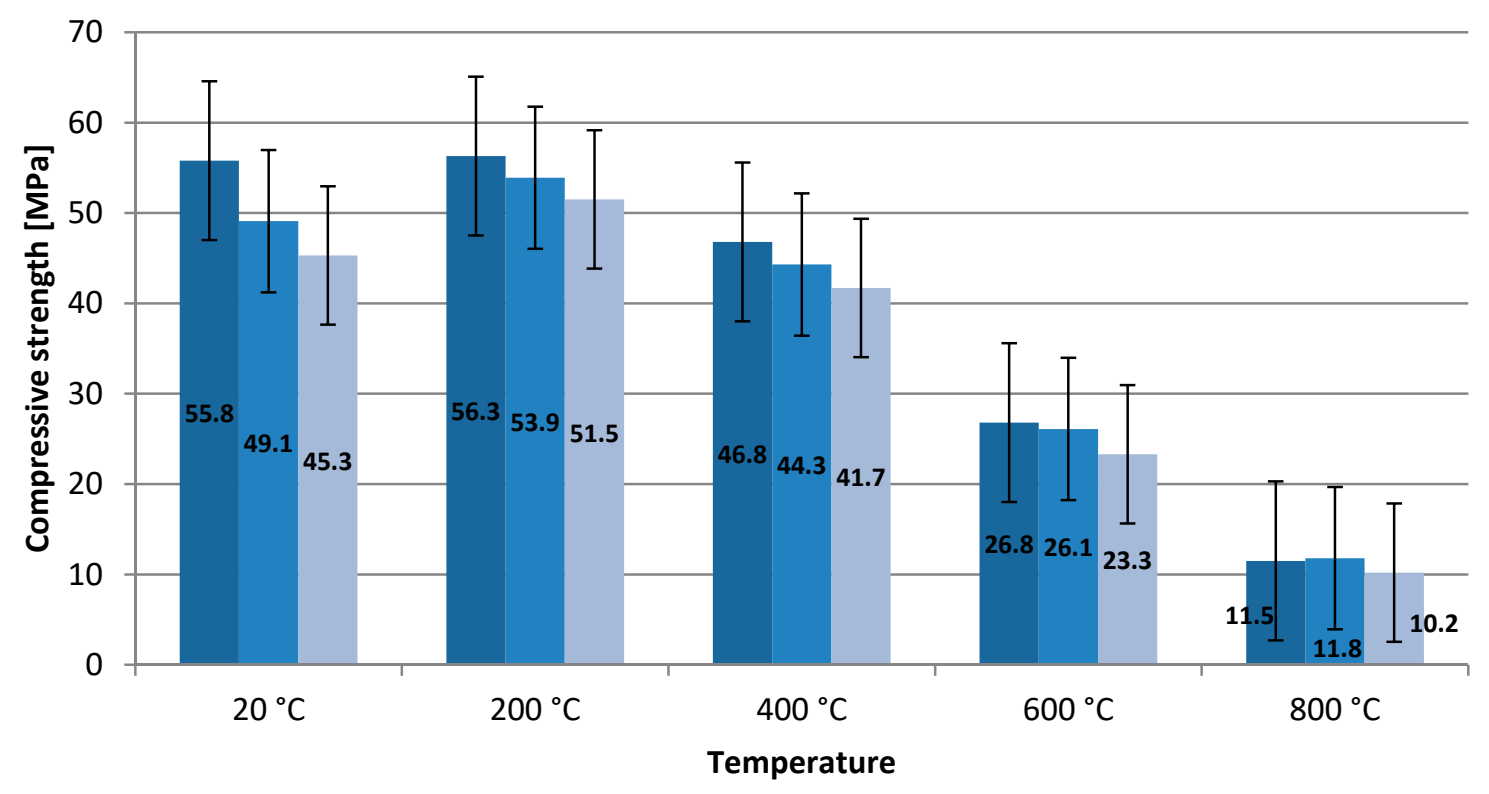

$\square \mathrm{C}-0 \quad \square \mathrm{C}-2.5 \square \mathrm{C}-7.5$

Figure 7. Compressive strength of concrete with heated composite after 180 days-10 cm cubes.

An increase was observed in average compressive strength after heating the up of the samples to a temperature of $200{ }^{\circ} \mathrm{C}$. The strength of C- 2.5 concrete grew by $4.8 \mathrm{MPa}$, and for the C-7.5 concrete by 6.2 $\mathrm{MPa}$ in relation to the strength determined at room temperature. On the other hand, it may be considered surprising that the strength of composite C-0 increased slightly. The cement composite did not lose its properties thanks to the low coefficient of thermal expansion and the good ability of borosilicate glass to work at temperatures up to $300{ }^{\circ} \mathrm{C}$. The impact of fire temperatures exceeding $400{ }^{\circ} \mathrm{C}$ causes a fall in strength by circa $16 \%(\mathrm{C}-0), 10 \%(\mathrm{C}-2.5), 8 \%(\mathrm{C}-7.5)$. At a temperature of $600{ }^{\circ} \mathrm{C}$ the concretes were found to have a reduction of as much as by $50 \%$ compared to samples made of reference concrete.

Using smaller contents of recyclate in the concrete has a positive effect on the strength of samples subjected to a fire.

A curve of multiple regression has been plotted for temperatures and for average strength (Figure 8) including a calculation of the correlation equation and application of the growth trend on the dispersion diagram. Once a suitable predictive equation has been obtained in the form of a function of the second degree polynomial, the following questions may be posed: How effective is the prediction for the dependent variable? In addition, what is the accuracy of an assessment of such effectiveness? Table 11 presents relations between two variables, i.e., the $\mathrm{r}$ Pearson correlation coefficient (describing direction and force), coefficient of determination $\mathrm{R}^{2}$ and the significance level for the given coefficient. 


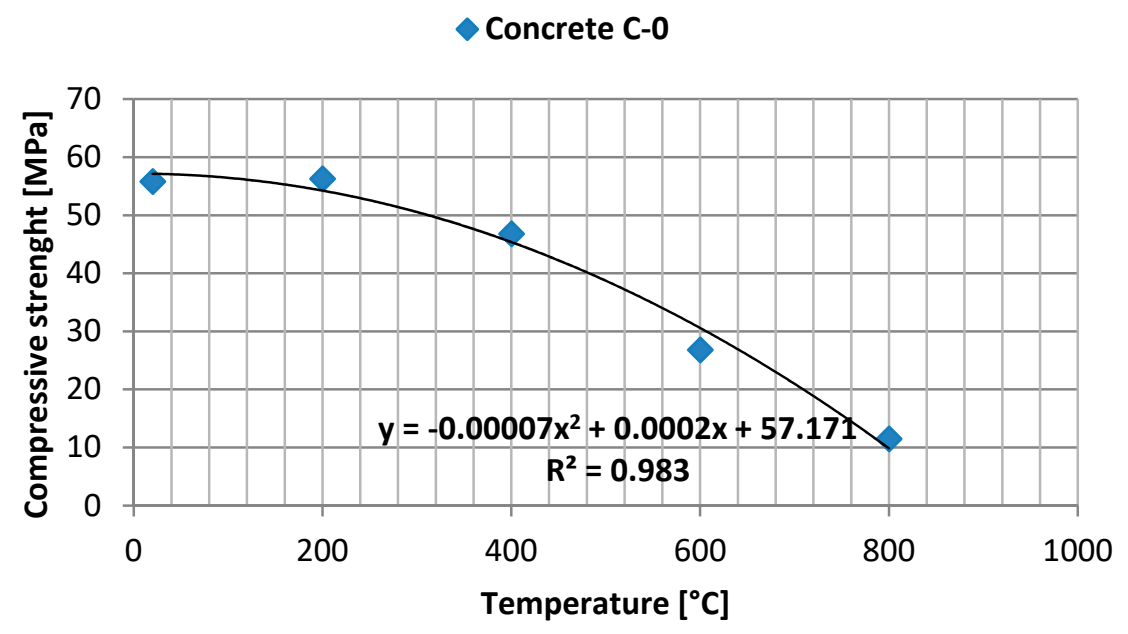

(a)

Concrete C-2.5

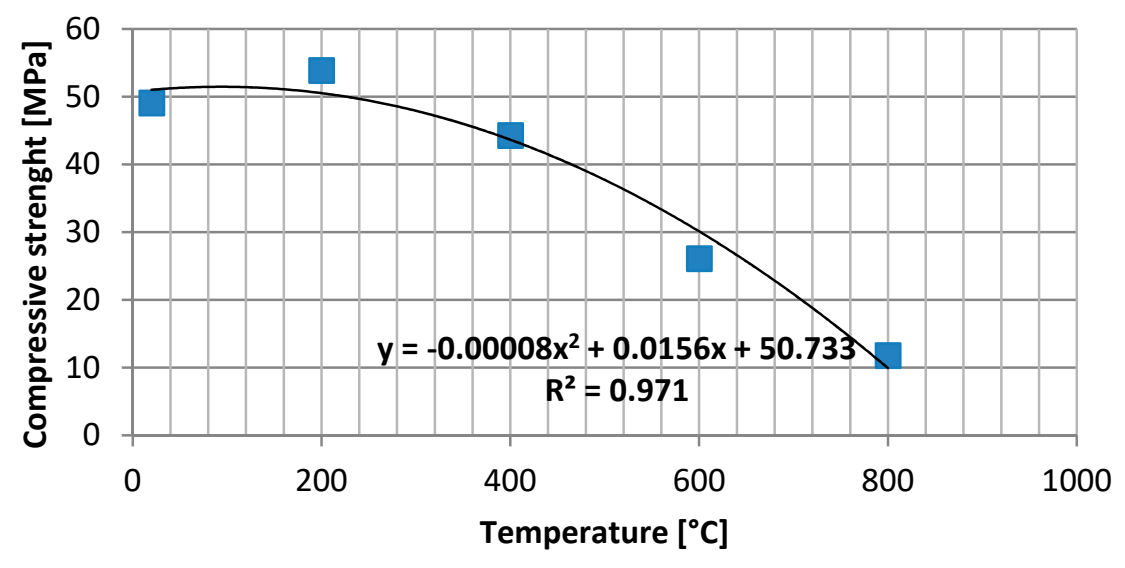

(b)

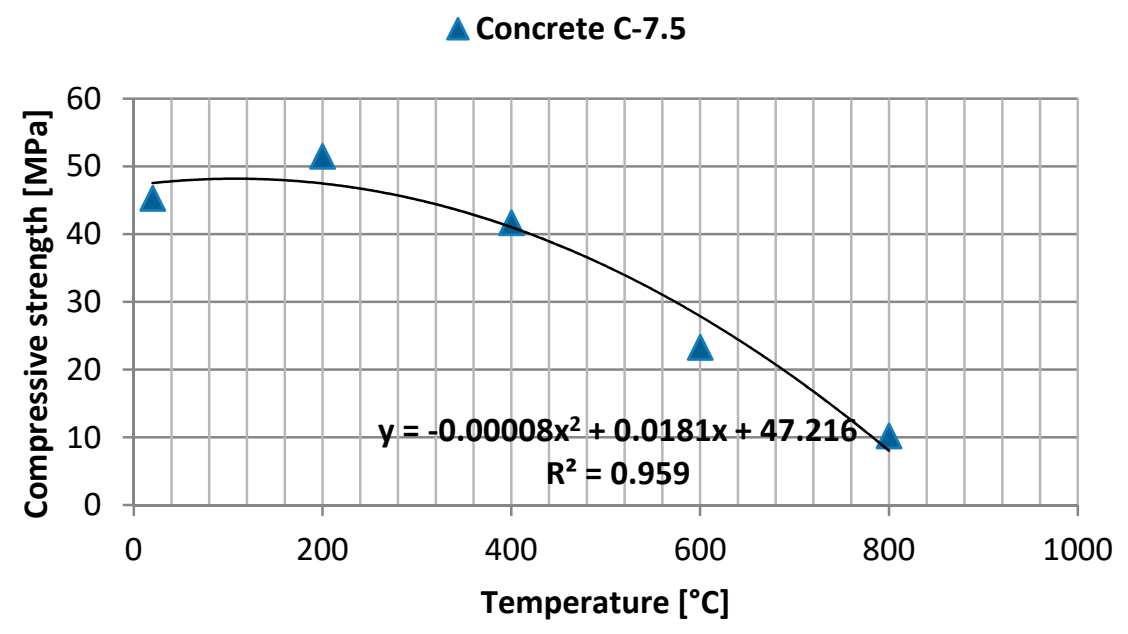

(c)

Figure 8. (a-c) Diagram of negative correlation. 
Table 11. Specification of relations between variables temperature-average strength.

\begin{tabular}{cccc}
\hline Concrete & C-0 & C-2.5 & C-7.5 \\
\hline r Pearson correlation coefficient & -0.991 & -0.985 & -0.979 \\
Coefficient of determination $\mathrm{R}^{2}$ & 0.983 & 0.971 & 0.959 \\
Significance level $\alpha$ & 0.001 & 0.002 & 0.004 \\
\hline
\end{tabular}

The obtained diagrams present a negative correlation, with a visible dependence ascertained between values, for which a decrease (increase) in strength is accompanied by an increase (decrease) in temperature. The coefficient of determination is significant at the level of 0.001 for C-0, 0.002 for C-2.5 and 0.004 for C-7.5.

\subsection{Concrete Testing in the Event of a Fire}

Before commencing the heating process, all samples were dried to constant mass. The testing was conducted according to the standard temperature-time curve according to EN 1991-1-2:2005 [71]. The samples were heated up in a special furnace at temperatures of $200{ }^{\circ} \mathrm{C}, 400{ }^{\circ} \mathrm{C}, 600{ }^{\circ} \mathrm{C}$ and $800{ }^{\circ} \mathrm{C}$. The heating time depended on the value of the programmed temperature. The temperature distribution in the pilot sample was recorded with the use of a computer equipped with dedicated software. The temperature distribution was monitored by four thermocouples (Figure 9). Openings for heating thermoelements were made in the central part of the sample ( $\mathrm{CH} 11), 25 \mathrm{~mm}$ from the edge of the base ( $\mathrm{CH} 9), 10 \mathrm{~mm}$ from the edge of the base $(\mathrm{CH} 8)$. The thermocouple $(\mathrm{CH} 10)$ was fixed to the lateral surface of the sample. The regulating thermoelement (RT) is introduced through the posterior wall and is close to the top part of the furnace. The depth of the drilling was $50 \mathrm{~mm}$.

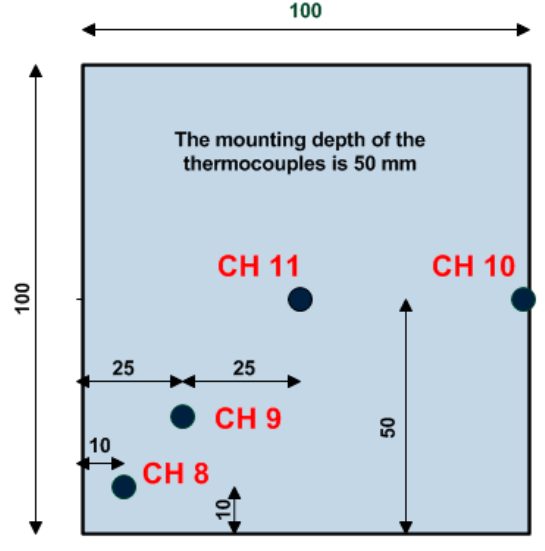

(a)

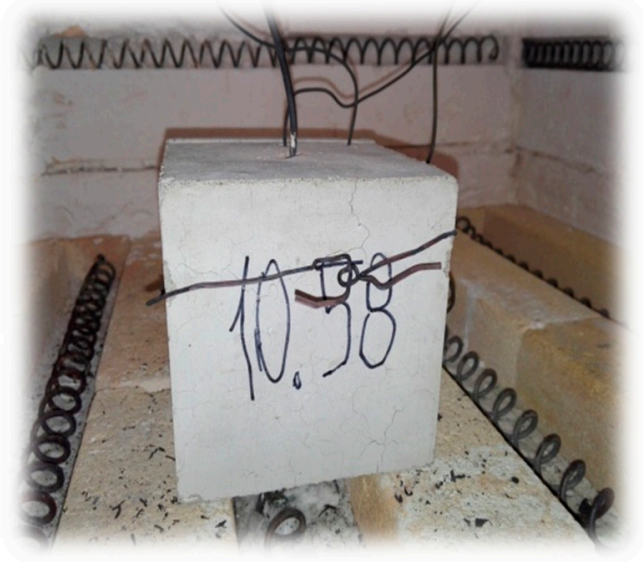

(b)

Figure 9. Cubic sample: (a) distribution of thermoelements; (b) sample with thermocouples.

An increase in temperature weakens the structure of the material. Cracking is visible on the sample surface. The actual distribution of temperatures shown in Figure 10 enables observations of the behaviour of concrete in the event of a fire.

Thermocouples distributed in the pilot sample enabled modelling the progress of standardised fire. The thermal process was programmed by specifying the time of heating, temperature, as well as the number of process sections that should be implemented.

The point at which the temperatures become balanced proves that the sample had been heated evenly throughout its entire volume. In the process of cooling down a visible increase occurs in the temperature of the internal layers [5]. 


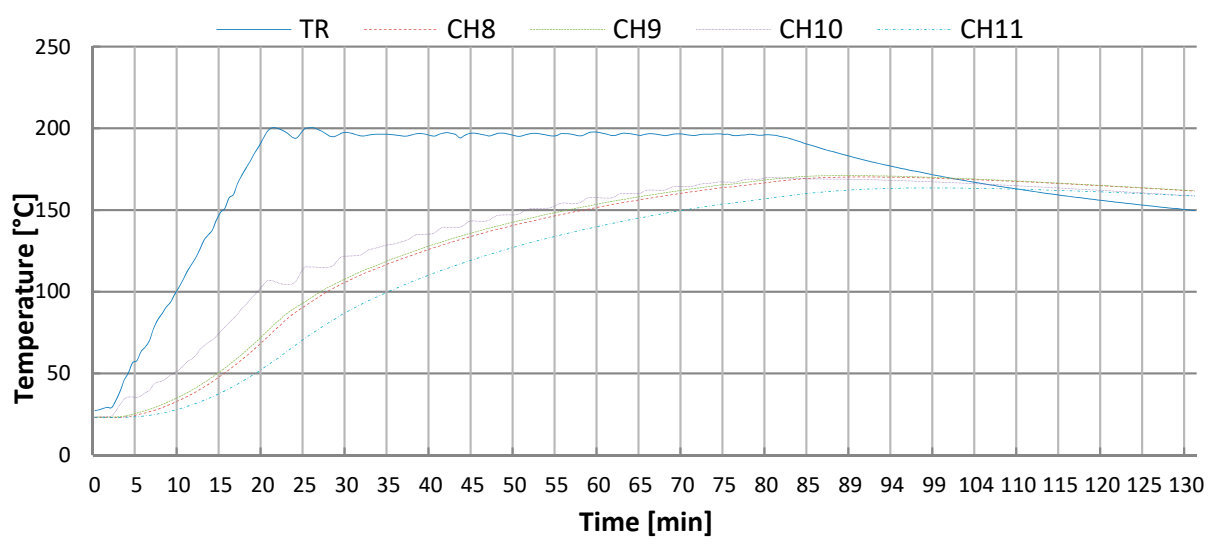

Figure 10. Temperature distribution in pilot sample of C-2.5. Heating curve to $200{ }^{\circ} \mathrm{C}$.

4.6. Scanning Electron Microscopy (SEM) with Energy Dispersive X-ray Spectroscopy (EDS) and X-ray Diffraction Analysis (XRD)

The paper presents a continuation of deliberations commenced in article [5], which are related by a common study subject pertaining to the impact of waste heat resistant glass cullet on the nature of phase transformations that take place in the heating phase. The studies comprised verification of microstructural properties and identification of phase composition. Tests were conducted on fracture surfaces of samples sustained in the destructive tests. Morphology of the glass obtained in the scanning microscope images are shown in Figure 11.

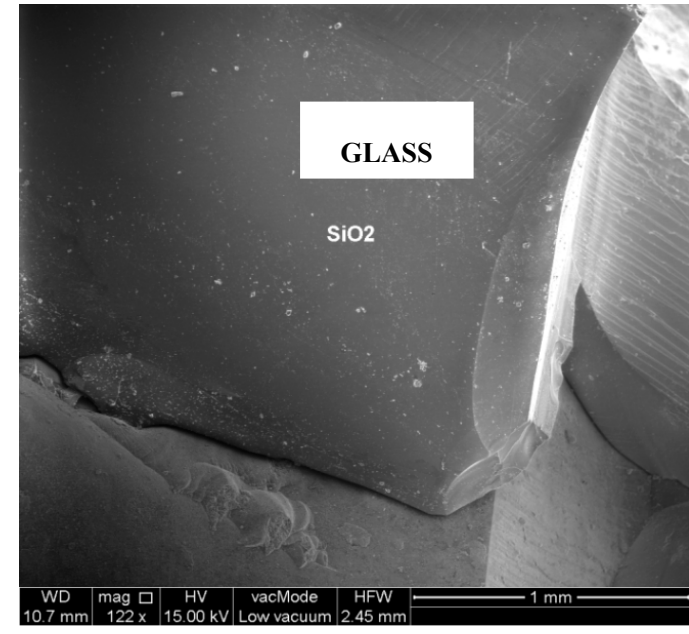

(a)

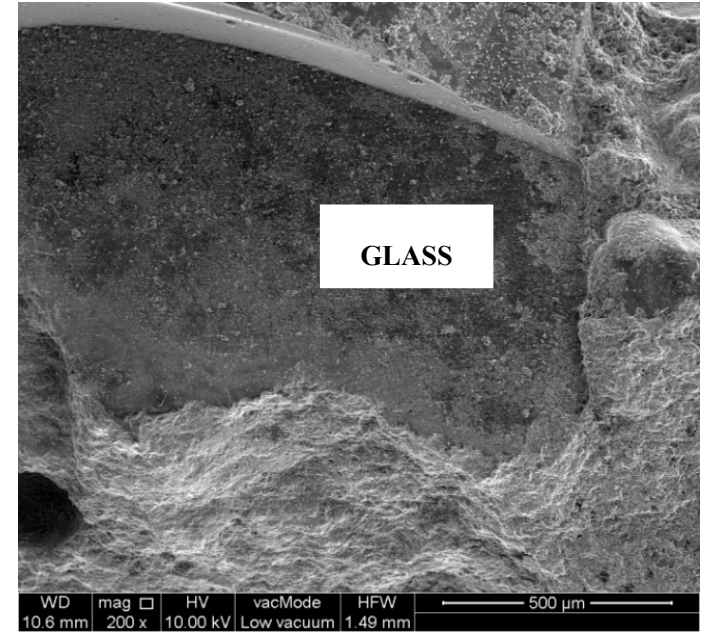

(b)

Figure 11. SEM. The microstructure of glass at temperatures of: (a) $20^{\circ} \mathrm{C} ;$ (b) $800{ }^{\circ} \mathrm{C}$.

Structural testing of the composition of heat-resistant glass (unheated at $20{ }^{\circ} \mathrm{C}$ and heated up to $800^{\circ} \mathrm{C}$ ) did not detect any significant changes. Glass is characterised by low resistance to the impact of alkali and significant resistance to water and strong acids. Silica glass $\mathrm{SiO}_{2}$ is characterised by a relatively low thermal expansion coefficient equalling circa $5 \times 10^{-7} \mathrm{~K}^{-1}$. Consequently, it is resistant to thermal shock and the occurring differences in temperature.

The chemical composition in the micro-area of cement composite samples was analysed using the EDS attachment. The testing also comprised analysis of the risk of dehydration of samples described in the literature [5,72]. The oxide composition of glass cullet is presented in Tables 12 and 13, and selected spectra of the chemical composition are shown in Figures 12-14. The chemical bonding of glass has a limited degree of modularity. As a non-crystalline (amorphous) structure, glass is characterised by 
transition to a liquid state during heating and a high degree of short-range modularity. The X-ray spectrum analysis defines the percentage content of particular oxides. The oxide composition of C-7.5 composite heated at $800{ }^{\circ} \mathrm{C}$, determined from point $\mathrm{A}$, is characterised by high contents of calcium oxide $\mathrm{CaO}(52.03 \%)$, silicon oxide (IV) $\mathrm{SiO}_{2}(22.32 \%)$, alumina $\mathrm{Al}_{2} \mathrm{O}_{3}(14.35 \%)$, sodium oxide $\mathrm{Na}_{2} \mathrm{O}$ $(0.98 \%)$ (Table 12$)$.

Table 12. Oxide composition of C-7.5 concrete with addition of heat-resistant glass determined from point A, weight $\%$.

\begin{tabular}{ccc}
\hline & $20^{\circ} \mathbf{C}$ & $\mathbf{8 0 0} \mathbf{C}$ \\
\cline { 2 - 3 } Oxides & \multicolumn{2}{c}{ Point $\mathbf{A}$} \\
\hline $\mathrm{Na}_{2} \mathrm{O}$ & $0.71 \%$ & $0.98 \%$ \\
$\mathrm{MgO}$ & $1.65 \%$ & $0.88 \%$ \\
$\mathrm{Al}_{2} \mathrm{O}_{3}$ & $19.10 \%$ & $14.35 \%$ \\
$\mathrm{SiO}_{2}$ & $17.60 \%$ & $22.32 \%$ \\
$\mathrm{SO}_{3}$ & $7.99 \%$ & $6.49 \%$ \\
$\mathrm{Cl}_{2} \mathrm{O}$ & $0.30 \%$ & $0.36 \%$ \\
$\mathrm{~K}_{2} \mathrm{O}$ & $0.82 \%$ & $0.56 \%$ \\
$\mathrm{CaO}$ & $48.17 \%$ & $52.03 \%$ \\
$\mathrm{Fe}_{2} \mathrm{O}_{3}$ & $3.64 \%$ & $2.02 \%$ \\
$\mathrm{Total}$ & $100.00 \%$ & $100.00 \%$ \\
\hline
\end{tabular}

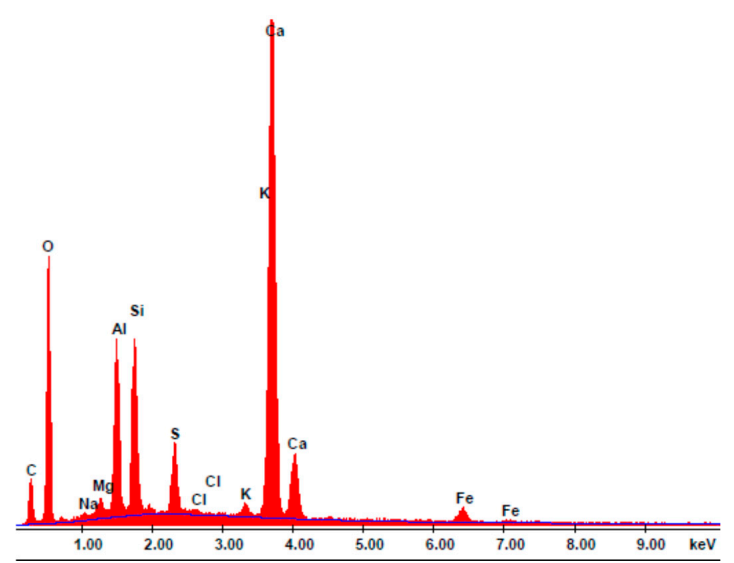

(a)

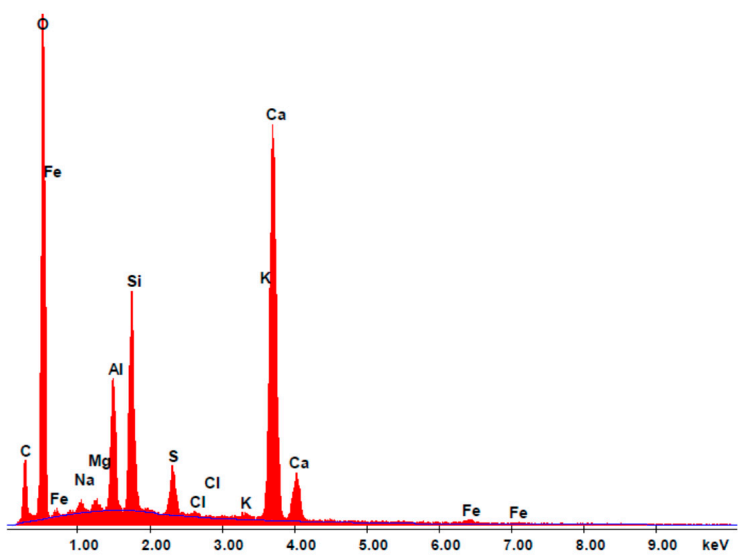

(c)

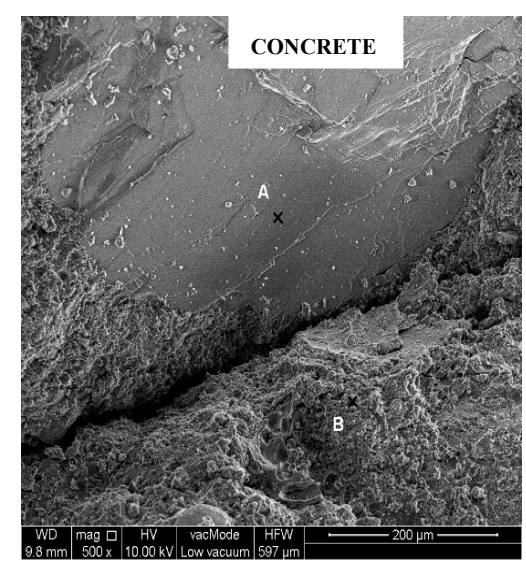

(b)

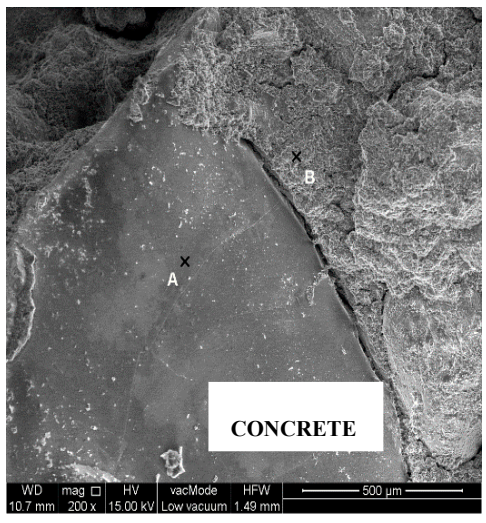

(d)

Figure 12. Analysis of the C-7.5 concrete determined from point B: (a) chemical composition spectrum of SEM-EDS, $20{ }^{\circ} \mathrm{C}$; (b) microstructure, $20{ }^{\circ} \mathrm{C}$; (c) chemical composition spectrum of SEM-EDS, $800{ }^{\circ} \mathrm{C}$; (d) microstructure, $800{ }^{\circ} \mathrm{C}$. 


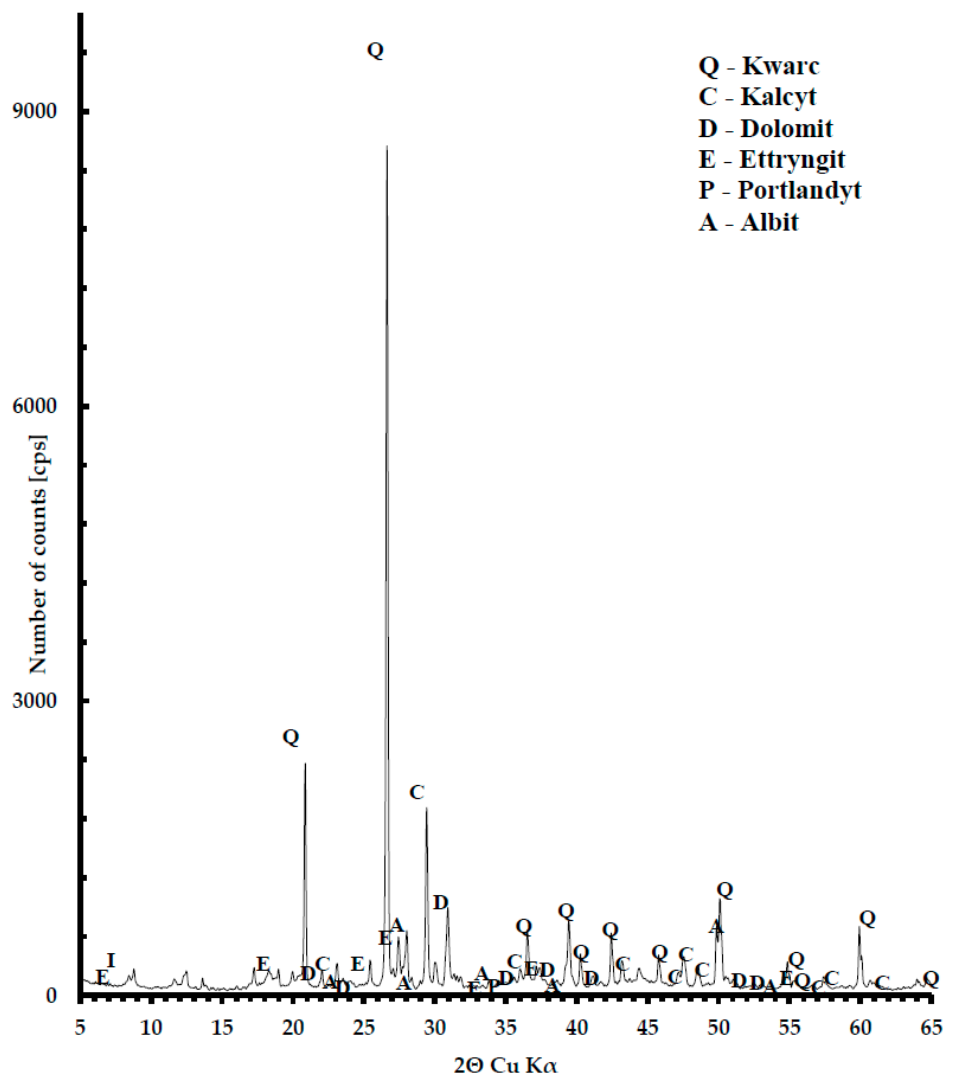

(a)

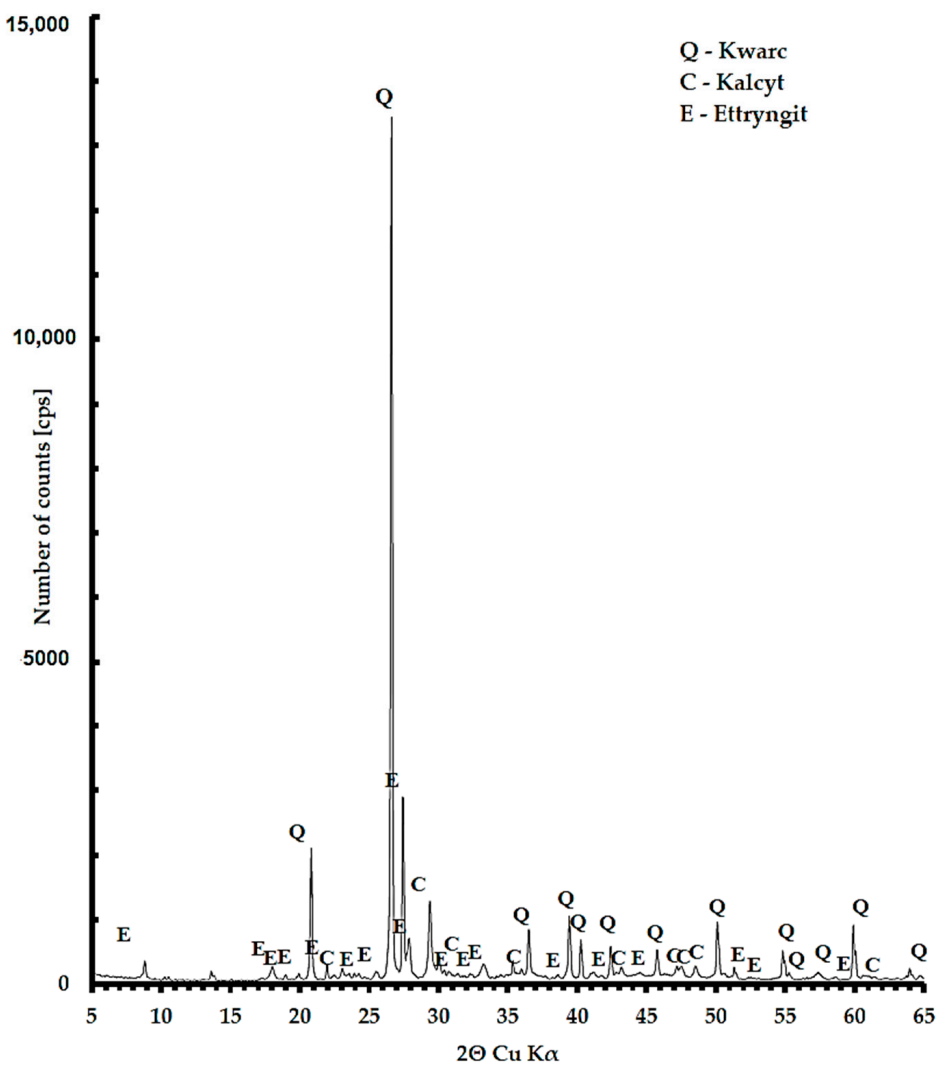

(b)

Figure 13. XRD analysis for C-7.5: (a) diffractogram, $20^{\circ} \mathrm{C}$; (b) diffractogram, $800^{\circ} \mathrm{C}$. 


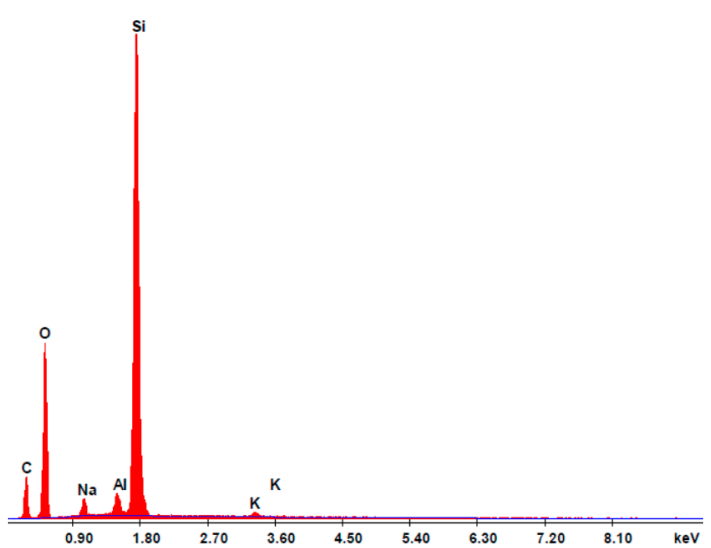

(a)

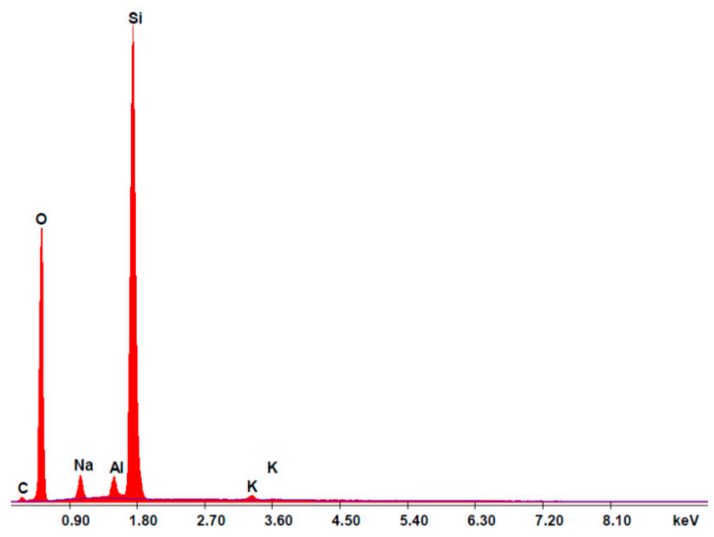

(c)

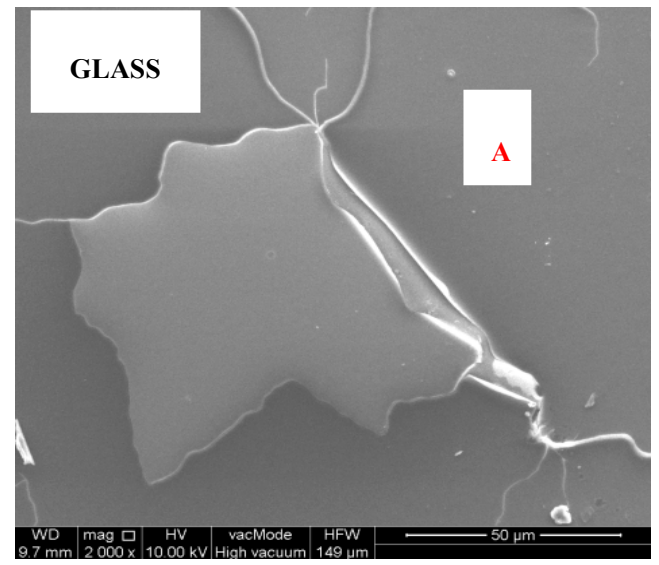

(b)

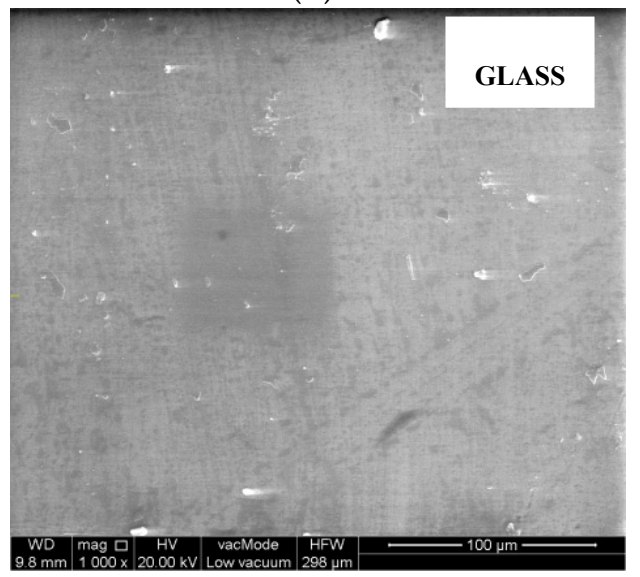

(d)

Figure 14. Analysis of glass cullet, $20^{\circ} \mathrm{C}$ : (a) chemical composition spectrum of SEM-EDS, point A; (b) microstructure of glass, point A; (c) SEM-EDS chemical composition spectrum, area; (d) glass microstructure, area.

The phase composition of concrete was determined using X-ray diffraction analysis (Figure 13). It is dominated by quartz recognized by the interplanar distances $\mathrm{d}=3.34,4.25 \AA$, calcite $\mathrm{d}=3.03$, $2.85,2.09 \AA$ and dolomite 2.87, 2.19, $1.78 \AA$. The sub-components are feldspars in the form of albite $\mathrm{d}=3.26,3.22$ and portlandite $\mathrm{d}=2.63,4.90 \AA$ and ettryngit $\mathrm{d}=9.76,3.87 \AA$. The process of heating to a temperature of $800{ }^{\circ} \mathrm{C}$ caused the entire decomposition of dolomite and portlandite, which initiated the process of carbonation of the cement binder.

The glass composition analysis was conducted after glass was subjected to the impact of temperatures of $20{ }^{\circ} \mathrm{C}$ and $800{ }^{\circ} \mathrm{C}$, with the determination made from point $\mathrm{A}$ and the area of the collected sample. The results are specified in Table 13. An analysis of the chemical composition of recyclate showed slight differences in the content of the main chemical components. The content of silicon oxide increases, at the expense of which the proportion of alkali oxides $\left(\mathrm{Na}_{2} \mathrm{O}\right.$ and $\left.\mathrm{K}_{2} \mathrm{O}\right)$ slightly decreases. The content of $\mathrm{Al}_{2} \mathrm{O}_{3}$ ranges from 3.68 to $4.69 \%$ which allows the statement that the tested concrete is thermally resistant.

The spectra of the chemical composition (Figures $14 \mathrm{a}, \mathrm{c}$ and 15a,c) confirm the presence of elements contained by glass cullet that originate from quartz $\left(\mathrm{SiO}_{2}\right)$ and oxides $\mathrm{K}_{2} \mathrm{O}, \mathrm{Na}_{2} \mathrm{O}$ among others. In addition, peaks coming from alumina $\mathrm{AL}_{2} \mathrm{O}_{3}$, which enhanced mechanical, chemical and thermal properties of silicate glass were ascertained. 
Table 13. Analysis of composition of glass cullet determined from point A and from the area-weight $\%$.

\begin{tabular}{ccccc}
\hline \multirow{2}{*}{ Oxides } & $\mathbf{2 0}{ }^{\circ} \mathbf{C}$ & $\mathbf{8 0 0}{ }^{\circ} \mathbf{C}$ & $20{ }^{\circ} \mathbf{C}$ & $800{ }^{\circ} \mathbf{C}$ \\
\cline { 2 - 5 } \multicolumn{2}{c}{ Point $\mathbf{A}$} & \multicolumn{2}{c}{ Area } \\
\hline $\mathrm{Na}_{2} \mathrm{O}$ & $2.81 \%$ & $2.76 \%$ & $3.99 \%$ & $3.38 \%$ \\
$\mathrm{Al}_{2} \mathrm{O}_{3}$ & $4.69 \%$ & $3.68 \%$ & $4.61 \%$ & $3.92 \%$ \\
$\mathrm{SiO}_{2}$ & $91.85 \%$ & $93.29 \%$ & $90.72 \%$ & $92.32 \%$ \\
$\mathrm{~K}_{2} \mathrm{O}$ & $0.62 \%$ & $0.26 \%$ & $0.68 \%$ & $0.37 \%$ \\
$\mathrm{SUMA}$ & $100.00 \%$ & $100.00 \%$ & $100.00 \%$ & $100.00 \%$ \\
\hline
\end{tabular}

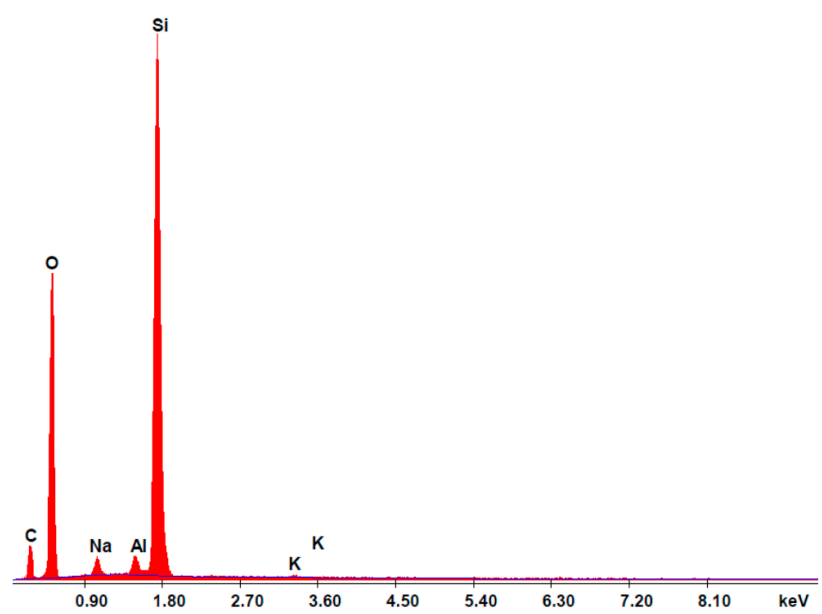

(a)

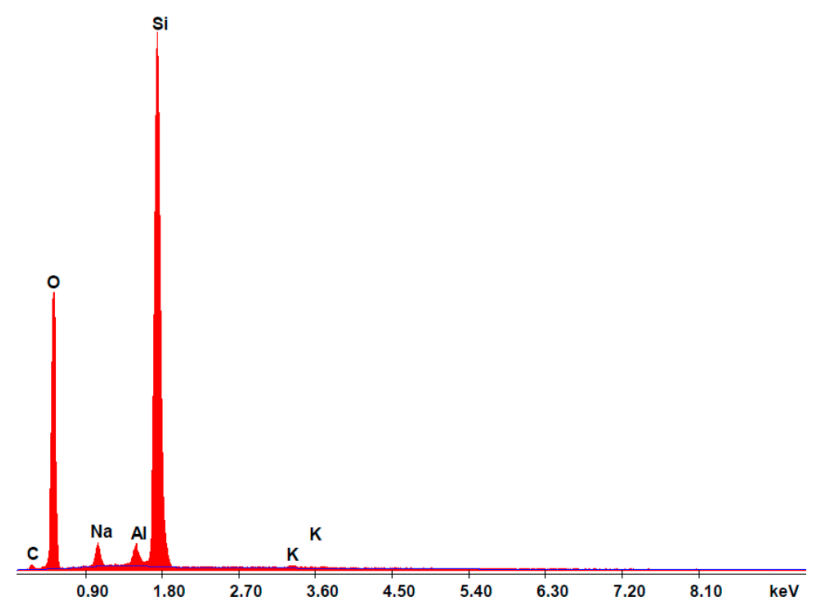

(c)

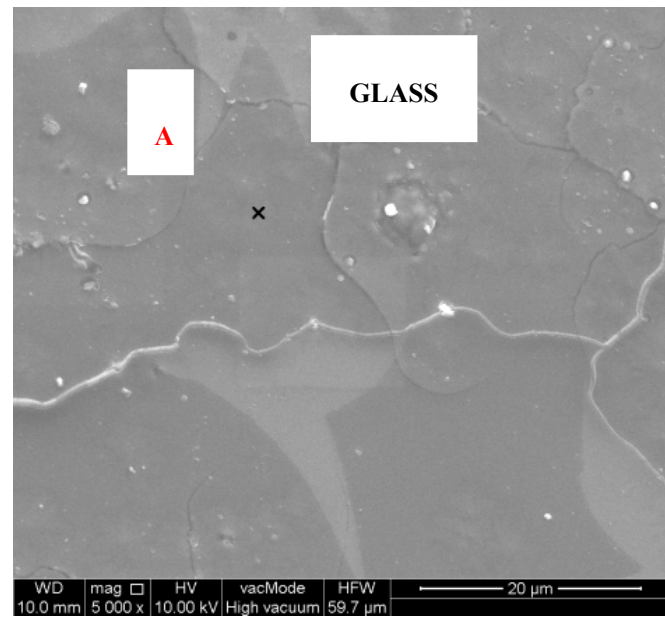

(b)

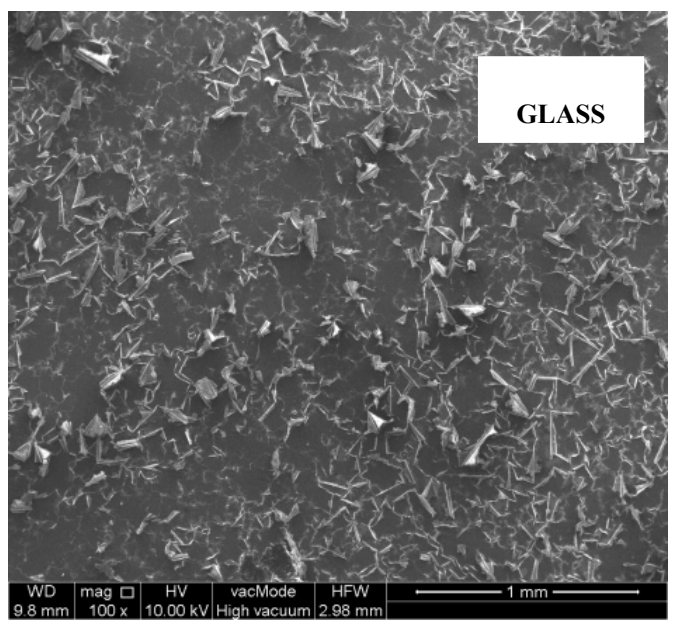

(d)

Figure 15. Analysis of oxide composition of glass cullet, $800{ }^{\circ} \mathrm{C}$ : (a) chemical composition spectrum of SEM-EDS, point A; (b) the microstructure of glass, point A; (c) SEM-EDS chemical composition spectrum, area; (d) glass microstructure, area.

Based on the conducted structural testing and data obtained from published studies pertaining to analyses of absorption spectra in infrared of Raman spectra, a presumption may be made that cement composite containing an additive of heat-resistant glass is less susceptible to strains resulting from thermal expansion [72-74]. The material is less susceptible to cracking after thermal shock. 


\section{Conclusions}

Source materials contain limited information as to the impact of fire-resistant cullet on the physical, mechanical and chemical properties of cement composite. Specific data obtained during the conducted experiment and the analysis of obtained results enable the formulation of the following final conclusions:

(1) The average compressive strength of concrete improved using $2.5 \%$ of waste glass cullet was found to be $48.6 \mathrm{MPa}$ and $49.1 \mathrm{MPa}$, respectively, after 28 and 180 days of curing.

(2) Replacement of $2.5 \%$ and $7.5 \%$ of natural aggregate (gravel and sand) with recycled aggregate allowed the attainment of concrete of class C30/37. Compared to reference concrete, a fall in strength was recorded. It may also be seen that the strength of the composite grows with the extension of the concrete curing time.

(3) The most advantageous temperature of firing amounted to $200{ }^{\circ} \mathrm{C}$. The composite was found to have an increase in strength by $6.2 \mathrm{MPa}$ after 180 days of curing.

(4) An excessively high temperature $\left(800{ }^{\circ} \mathrm{C}\right)$ causes damage to gravel grains which caused an impairment of the properties of hardened concrete. In the composites, compressive strength decreased by circa $50 \%$.

(5) The mass loss of the C-2.5 composite did not exceed 1\% (the admissible value is 6\%). Concrete may be successfully used as a fire partition wall.

(6) Testing pointed to the existence of concentrations of selected elements, which remained within acceptable levels.

(7) Glass cullet (borosilicate glass) used for testing was not found to have changes to the structure and composition after the impact of temperature at the level of $800{ }^{\circ} \mathrm{C}$.

(8) The correlation between average compressive strength and temperature is significant and equals 0.004 for C-7.5 concrete.

The heat resistant glass cullet is not biodegradable and offers satisfactory performance parameters. Appropriate disposal and processing allow multiple re-use. Based on the conducted studies and analyses it has been proven that waste obtained from broken dishes may serve as perfect supplementation for aggregate of natural origin and can replace coarse aggregate used for concrete. Given environmental standards, it may be presumed that composite is an ecological full-value construction material.

The authors are conducting additional tests to analyse the impact of ground glass cullet on properties of cement composite. Those studies are expected to broaden the available knowledge and to determine features of concrete not included in the programme of the present study.

Author Contributions: Conceptualization, A.P., J.S. and P.O.; methodology, A.P., J.S. and P.O.; formal analysis, A.P.; investigation, A.P. and P.O.; data curation, A.P.; writing-original draft preparation, A.P.; writing-review and editing, A.P. and P.O.; supervision, A.P.; project administration, A.P. and P.O.; funding acquisition, P.O. All authors have read and agreed to the published version of the manuscript.

Funding: This research received no external funding.

Conflicts of Interest: The authors declare that there is no conflict of interest with any financial organization regarding the material discussed in the manuscript.

\section{References}

1. Jóźwik, A. Rozwiązania konstrukcyjne w aspekcie nowych technologii szkła. Wydaw. Politech. Warsz. 2007, 104, 219-222.

2. Abramowicz, M.; Adamski, R.G. Bezpieczeństwo Pożarowe Budynków, cz. 1; Szkoła Główna Służby Pożarniczej: Warsaw, Poland, 2002; pp. 59-72.

3. Cholerzyński, W.; Hetmann, A.; Pielka, K. Elementy Bezpieczeństwa Pożarowego Budynków dla Stuchaczy Kursów Kwalifikowanych Szeregowych i Podoficerów PSP; Komenda Główna Państwowej Straży Pożarnej Fundacja Edukacyjna i Technika Ratownictwa: Warsaw, Poland, 2005; pp. 37-41. 
4. Recykling Szkła. Available online: https://www.oostdam.pl/recykling-szkla/ (accessed on 30 March 2020).

5. Powęzka, A.; Szulej, J.; Ogrodnik, P. Effect of High Temperatures on the Impact Strength of Concrete Based on Recycled Aggregate Made of Heat-Resistant Cullet. Materials 2020, 13, 465. [CrossRef]

6. Bernardo, E. Mechanical properties of metal-particulate lead-silicate glass matrix composites obtained by means of powder technology. J. Eur. Ceram. Soc. 2003, 23, 1819-1827. [CrossRef]

7. Heart, S. Recycling of cathodic ray tubes (CRTs) in electronic waste. CLEAN-Soil Air Water 2008, 36, 19-24.

8. Kim, K.; Kim, K.; Hwang, J. Characterization of ceramic tiles containing LCD waste glass. Ceram. Int. 2016, 42, 7626-7631. [CrossRef]

9. Kumar, S.; Nagar, B. Effects of Waste Glass Powder on Compressive Strength of Concrete. Int. J. Trend Sci. Res. Dev. 2017, 1, 289-298. [CrossRef]

10. Góra, J.; Franus, M.; Barnat-Hunek, D.; Franus, W. Utilization of Recycled Liquid Crystal Display (LCD) Panel Waste in Concrete. Materials 2019, 12, 2941. [CrossRef]

11. Powęzka, A.; Ogrodnik, P.; Biedugnis, S.; Szulej, J. Assessment of selected parameters of concrete composite containing recyclate obtained from fire-resistant cullet. J. Physics Conf. Ser. 2019, 1398, 012011. [CrossRef]

12. Recycling Glass_-How It Helps Environment. Available online: https://wwf.panda.org/knowledge_hub/ teacher_resources/project_ideas/recycling_glass.cfm (accessed on 8 April 2020).

13. Drzymała, T.; Zegardło, B.; Tofilo, P. Properties of Concrete Containing Recycled Glass Aggregates Produced of Exploded Lighting Materials. Materials 2020, 13, 226. [CrossRef]

14. Meddah, M.S. Use of Waste Window Glass as Substitute of Natural Sand in Concrete Production. IOP Conf. Ser.: Mater. Sci. Eng. 2019, 603, 032011. [CrossRef]

15. He, Z.; Zhan, P.-M.; Du, S.-G.; Liu, B.-J.; Yuan, W.-B. Creep behavior of concrete containing glass powder. Compos. Part B: Eng. 2019, 166, 13-20. [CrossRef]

16. Meda, A.; Rinaldi, Z.; Spagnuolo, S.; De Rivaz, B.; Giamundo, N. Hybrid precast tunnel segments in fiber reinforced concrete with glass fiber reinforced bars. Tunn. Undergr. Space Technol. 2019, 86, 100-112. [CrossRef]

17. Liu, H.; Shi, J.; Qu, H.; Ding, D.-X. An investigation on physical, mechanical, leaching and radiation shielding behaviors of barite concrete containing recycled cathode ray tube funnel glass aggregate. Constr. Build. Mater. 2019, 201, 818-827. [CrossRef]

18. Kim, I.-S.; Choi, S.Y.; Yang, E.I. Evaluation of durability of concrete substituted heavyweight waste glass as fine aggregate. J. Constr. Build. Mater. 2018, 184, 269-277. [CrossRef]

19. Lee, H.; Hanif, A.; Usman, M.; Sim, J.; Oh, H. Performance evaluation of concrete incorporating glass powder and glass sludge wastes as supplementary cementing material. J. Clean. Prod. 2018, 170, 683-693. [CrossRef]

20. Islam, G.S.; Rahman, M.; Kazi, N. Waste glass powder as partial replacement of cement for sustainable concrete practice. Int. J. Sustain. Built Environ. 2017, 6, 37-44. [CrossRef]

21. Zhang, L.; Zhang, Y.; Liu, C.; Liu, L.; Tang, K. Study on microstructure and bond strength of interfacial transition zone between cement paste and high-performance lightweight aggregates prepared from ferrochromium slag. J. Constr. Build. Mater. 2017, 142, 31-41. [CrossRef]

22. Biolzi, L.; Cattaneo, S.; Crespi, P.; Giordano, N. Damage in glass-concrete composite panels. J. Constr. Build. Mater. 2016, 116, 235-244. [CrossRef]

23. Omran, A.; Tagnit-Hamou, A. Performance of glass-powder concrete in field applications. J. Constr. Build. Mater. 2016, 109, 84-95. [CrossRef]

24. Matteucci, F.; Dondi, M.; Guarini, G. Effect of soda-lime glass on sintering and technological properties of porcelain stoneware tiles. Ceram. Int. 2002, 28, 873-880. [CrossRef]

25. Tucci, A.; Esposito, L.; Rastelli, E.; Palmonari, C.; Rambaldi, E. Use of soda-lime scrap-glass as a fluxing agent in a porcelain stoneware tile mix. J. Eur. Ceram. Soc. 2004, 24, 83-92. [CrossRef]

26. Pontikes, Y.; Christogerou, A.; Angelopoulos, G.N.; Esposito, L.; Tucci, A. On the addition of soda-lime scrap glass for the production of heavy clay ceramics. Ceramurg. Ceram. Acta 2004, 34, 199-206.

27. Dondi, M.; Guarini, G.; Raimondo, M.; Zanelli, C. Recycling PC and TV waste glass in clay bricks and roof tiles. Waste Manag. 2009, 29, 1945-1951. [CrossRef]

28. Palmonari, C.; Tenaglia, A. Manufacture of heavy-clay products with the addition of residual sludges from other ceramic industries. Miner. Petrogr. Acta 1985, 29, 547-562.

29. Andreola, F.; Barbieri, L.; Corradi, A.; Lancellotti, I. CRT glass state of the art. J. Eur. Ceram. Soc. 2007, 27, 1623-1629. [CrossRef] 
30. Shi, C.; Wu, Y.; Shao, Y.; Riefler, C. Alkali-aggregate reaction of concrete containing ground glass powder. In Proceedings of the 12th International Conference on AAR in Concrete, Beijing, China, 15-19 October 2004; pp. 789-795.

31. Kim, K.; Kim, K.; Hwang, J. LCD waste glass as a substitute for feldspar in the porcelain sanitary ware production. Ceram. Int. 2015, 41, 7097-7102. [CrossRef]

32. Najduchowska, M.; Różycka, K.; Rolka, G. Ocena możliwości wykorzystania stłuczki szklanej w przemyśle budowlanym w aspekcie jej wpływu na środowisko naturalne. Sci. Works Inst. Ceram. Build. Mater. 2014, 17, 46-56.

33. Degirmenci, N.; Yilmaz, A.; Cakir, O.A. Utilization of waste glass as sand replacement in cement mortar. Indian J. Eng. Mater. Sci. 2011, 18, 303-308.

34. Terro, M.J. Properties of concrete made with recycled crushed glass at elevated temperatures. Build. Environ. 2006, 41, 633-639. [CrossRef]

35. Schwarz, N.; Cam, H.; Neithalath, N. Influence of a fine glass powder on the durability characteristics of concrete and its comparison to fly ash. Cem. Concr. Compos. 2008, 30, 486-496. [CrossRef]

36. Nassar, R.; Soroushian, P. Strength and durability of recycled aggregate concrete containing milled glass as partial replacement for cement. Constr. Build. Mater. 2012, 29, 368-377. [CrossRef]

37. Aly, M.; Hashmi, M.; Olabi, A.; Messeiry, M.; Abadir, E.; Hussain, A. Effect of colloidal nano-silica on the mechanical and physical behaviour of waste-glass cement mortar. Mater. Des. 2012, 33, 127-135. [CrossRef]

38. Pawluczuk, E.; Kalinowska-Wichrowska, K.; Bołtryk, M.; Jiménez, J.R.; Fernández, J.M. The Influence of Heat and Mechanical Treatment of Concrete Rubble on the Properties of Recycled Aggregate Concrete. Materials 2019, 12, 367. [CrossRef] [PubMed]

39. Liu, G.; Florea, M.; Brouwers, H. Performance evaluation of sustainable high strength mortars incorporating high volume waste glass as binder. Constr. Build. Mater. 2019, 202, 574-588. [CrossRef]

40. Shi, C.; Zheng, K. A review on the use of waste glasses in the production of cement and concrete. Resour. Conserv. Recycl. 2007, 52, 234-247. [CrossRef]

41. Omrane, M.; Kenai, S.; Kadri, E.-H.; Aït-Mokhtar, A. Performance and durability of self compacting concrete using recycled concrete aggregates and natural pozzolan. J. Clean. Prod. 2017, 165, 415-430. [CrossRef]

42. Omran, A.; Harbec, D.; Tagnit-Hamou, A.; Gagne, R. Production of roller-compacted concrete using glass powder: Field study. Constr. Build. Mater. 2017, 133, 450-458. [CrossRef]

43. Omran, A.F.; Etienne, D.; Harbec, D.; Tagnit-Hamou, A. Long-term performance of glass-powder concrete in large-scale field applications. Constr. Build. Mater. 2017, 135, 43-58. [CrossRef]

44. Soliman, N.A.; Tagnit-Hamou, A. Partial substitution of silica fume with fine glass powder in UHPC: Filling the micro gap. Constr. Build. Mater. 2017, 139, 374-383. [CrossRef]

45. Du, H.; Tan, K.H. Properties of high volume glass powder concrete. Cem. Concr. Compos. 2017, 75, 22-29. [CrossRef]

46. Ramakrishnan, K.; Pugazhmani, G.; Sripragadeesh, R.; Muthu, D.; Venkatasubramanian, C. Experimental study on the mechanical and durability properties of concrete with waste glass powder and ground granulated blast furnace slag as supplementary cementitious materials. Constr. Build. Mater. 2017, 156, 739-749. [CrossRef]

47. Lu, J.-X.; Zhan, B.-J.; Duan, Z.-H.; Poon, C.S. Using glass powder to improve the durability of architectural mortar prepared with glass aggregates. Mater. Des. 2017, 135, 102-111. [CrossRef]

48. Aliabdo, A.A.; Elmoaty, A.E.M.A.; Aboshama, A.Y. Utilization of waste glass powder in the production of cement and concrete. Constr. Build. Mater. 2016, 124, 866-877. [CrossRef]

49. Afshinnia, K.; Rangaraju, P.R. Impact of combined use of ground glass powder and crushed glass aggregate on selected properties of Portland cement concrete. Constr. Build. Mater. 2016, 117, 263-272. [CrossRef]

50. Soliman, N.A.; Tagnit-Hamou, A. Development of ultra-high-performance concrete using glass powder-Towards ecofriendly concrete. Constr. Build. Mater. 2016, 125, 600-612. [CrossRef]

51. Al-Zubaid, A.B.; Shabeeb, K.M.; Ali, A.I. Study the Effect of Recycled Glass on the Mechanical Properties of Green Concrete. Energy Procedia 2017, 119, 680-692. [CrossRef]

52. Gesoglu, M.; Güneyisi, E.; Öznur, H.; Taha, I.; Taner, M. Failure characteristics of self-compacting concretes made with recycled aggregates. Constr. Build. Mater. 2015, 98, 334-344. [CrossRef]

53. De Castro, S.; De Brito, J. Evaluation of the durability of concrete made with crushed glass aggregates. J. Clean. Prod. 2013, 41, 7-14. [CrossRef] 
54. Wang, H.Y.; Zeng, H.H.; Wu, J.Y. A study on the macro and micro properties of concrete with LCD glass. Constr. Build. Mater. 2014, 50, 664-670. [CrossRef]

55. Wang, H.Y.; Huang, W.L. Durability of self-consolidating concrete using waste LCD glass. Constr. Build. Mater. 2010, 24, 1008-1013. [CrossRef]

56. Ogrodnik, P.; Zegardło, B.; Radzikowska, M. Use of post-production sanitary ceramic waste as a filler in cement composites of high chemical resistance. Przemyst Chem. 2017, 96, 1100-1104. [CrossRef]

57. Ogrodnik, P.; Zegardło, B.; Szelag, M. The Use of Heat-Resistant Concrete Made with Ceramic Sanitary Ware Waste for a Thermal Energy Storage. Appl. Sci. 2017, 7, 1303. [CrossRef]

58. Rutkowska, G.; Wichowski, P.; Fronczyk, J.; Franus, M.; Chalecki, M. Use of fly ashes from municipal sewage sludge combustion in production of ash concretes. Constr. Build. Mater. 2018, 188, 874-883. [CrossRef]

59. Fly Ash for Concrete. Definition, Specifications and Conformity Criteria; EN 450-1:2012; BSI: London, UK, 2012.

60. Zegardło, B.; Maciej, S.; Ogrodnik, P.; Bombik, A. Physico-Mechanical Properties and Microstructure of Polymer Concrete with Recycled Glass Aggregate. Materials 2018, 11, 1213. [CrossRef] [PubMed]

61. Test of Geometrical Properties of Aggregates. Part 1: Determination of Particle Size Distribution-Sieving Method; EN 933-1: 2012; European Committee for Standardization: Brussels, Belgium, 2012.

62. Testing Hardened Concrete. Compressive Strength of Test Specimens; EN 12390-3:2009; BSI: London, UK, 2009.

63. Testing Fresh Concrete. Part 2: Slump—test; EN 12350-2:2009; BSI: London, UK, 2009.

64. Testing Fresh Concrete. Density; EN 12350-6:2009; BSI: London, UK, 2009.

65. Concrete. Specification, Performance, Production and Conformity; EN 206:2013; BSI: London, UK, 2013.

66. Testing Hardened Concrete. Making and Curing Specimens for Strength Tests; EN 12390-2:2019; BSI: London, UK, 2019.

67. Thermocouples. Part 1: EMF Specifications and Tolerances; IEC 60584-1:2013; IS.; English/French; IEC: Geneva, Switzerland, 2013.

68. Borek, K.; Czapik, P.; Dachowski, R. Recycled Glass as a Substitute for Quartz Sand in Silicate Products. Materials 2020, 13, 1030. [CrossRef] [PubMed]

69. Common Rules for Precast Concrete Products; EN 13369:2018; BS: London, UK, 2018.

70. Wawrzęczyk, J.; Molendowski, A.; Kozak, A. Wpływ wybranych czynników na wyniki badania nasiąkliwości betonu. Bud. Archit. 2013, 12, 239-246.

71. Eurocode 1: Actions on Structures. Part 1-2: General Actions-Actions on Structures Exposed to Fire; EN 1991-1-2:2005; ES: Brussels, Belgium, 2005.

72. Gawlicki, M.; Bobrowski, A.; Spyrka, J. Immobilizacja metali ciężkich w zaczynach cementowych. Pr. Kom. Nauk Ceram. PAN 1994, 46, 237-241.

73. Diamond, S. The microstructures of cement paste in concrete. In Proceedings of the 8th International Congress on the Chemistry of Cement, Rio de Janeiro, Brazil, 22-27 September 1986; pp. 2-9.

74. Zatryb, G.; Podhorodecki, A.; Misiewicz, J.; Cardin, J.; Gourbilleau, F. On the nature of the stretched exponential photoluminescence decay for silicon nanocrystals. Nanoscale Res. Lett. 2011, 6, 106. [CrossRef] [PubMed]

(C) 2020 by the authors. Licensee MDPI, Basel, Switzerland. This article is an open access article distributed under the terms and conditions of the Creative Commons Attribution (CC BY) license (http://creativecommons.org/licenses/by/4.0/). 